\title{
ART, CULTURE AND SERVICE: THE DEPICTION OF SOLDIERS ON FUNERARY MONUMENTS OF THE 3RD CENTURY AD
}

\author{
Jon Goulston
}

By far the most numerous depictions of soldiers in Roman art are to be found sculpted on the state 'propaganda' monuments of the 1st to 4th centuries AD, whether still standing, as in the cases of the Column of Trajan and the Arch of Severus in Rome, or represented by disiecta membra, as with the fragments of the Columns of Theodosius and Arcadius in Istanbul. ${ }^{1}$ However, these works were the products of metropolitan workshops and of sculptors whose first priority might not necessarily have been to accurately reproduce the contemporary appearance of soldiers. ${ }^{2}$ At the very least, the sheer scale of these sculptural projects enforced some degree of stylisation and simplification going beyond the

1 Trajan's Column involved the sculpting of 2,640 human figures on its helical frieze, 1,732 of which are Roman soldiers. See J.C.N. Coulston, All the Emperor's Men: Roman Soldiers and Barbarians on Trajan's Column (Oxford forthcoming). Later columns eschewed the same numbers, simplifying detail and scenery in favour of visibility from a distance. The frieze of the Column of Marcus Aurelius bore approximately 1,766 figures (E. Petersen, A. von Domaszewski and G. Calderini, Die Marcus-Säule auf der Piazza Colonna in Rom (Munich 1896)). The Arch of Severus in the Forum Romanum has figural representations on its 'siege' panels (485), its triumphal friezes (124) and on its pedestals (65) of which a total of 461 are soldiers (R. Brilliant, The Arch of Septimius Severus in the Forum Romanum. Memoirs of the American Academy in Rome 29 (Roma 1967); G.M. Koeppel, ,Die historischen Reliefs der römischen Kaiserzeit VII. Der Bogen des Septimius Severus, die Decennalienbasis und der Konstantinsbogen', Bonner Fahrbücher 190 (1990), 12-31).

The writer would like to thank the following individuals for discussing various issues in conjunction with this paper: Jeremy Armstrong, Mike Bishop, Alexandra Busch, Hazel Dodge, Thomas Fischer, Andrew Gammon, Simon James, Jurgen Oldenstein, Robin Osborne, Guy Stiebel, Oliver Stoll and Hans-Jorg Ubl. Research for this paper was carried out during leave supported by the University of St Andrews and the Arts and Humanities Research Council, and whilst the writer was a Visiting Scholar in the School of Classics, Trinity College Dublin.

2 Although it is important to be aware that Trajan's Column did represent a new concern to reproduce contemporary military figures, albeit with a range of Hellenizing elements. See J.G.N. Coulston, 'The value of Trajan's Column as a source for Roman military equipment', in C. van Driel-Murray, ed., Roman Military Equipment: the Sources of Evidence, Proceedings of the Fifth Roman Military Equipment Conference (Oxford 1989), 31-44; Coulston forthcoming, op. cit. (n. 1). 
long-established artistic conventions of depicting battle and triumph.

Fortunately, there is another Roman iconographic source in the form of the very numerous figural funerary monuments privately erected in honour of individual soldiers. These cover a wide chronological range from the later 1 st century $\mathrm{BC}$ to the later 4 th century $\mathrm{AD}$. They were erected in Rome, Italy and the wider provinces, especially along the imperial frontiers. They depict almost all branches of military service, citizen and non-citizen, infantry and cavalry, praetoriani and legionarii, auxiliarii and classiarii, milites and veterani. The vast majority commemorate ranks from centurio downwards. By their nature as private dedications, and despite their own elements of stylisation and genericisation, these depictions do allow the modern observer to move closer to Roman soldiers, both as a distinct body within or on the fringes of Roman society, and as individuals proudly advertising service and achievement.

Within this chronologically and geographically widespread genre, there is one class which stands out as particularly rich and informative. These are the 3rd century monuments, sometimes referred to as 'ringbuckle gravestones.' Not all display the characteristic belt-buckle form, and not all comprise gravestones, strictly speaking, but include standing stelae, funerary altars, sarcophagi and painted 'mummy' portraits. To these may be added non-funerary soldiers on other 3rd century sculptures, floor mosaics, wall paintings, dipinti and graffiti. ${ }^{3}$ However, together

\footnotetext{
${ }^{3}$ For example, a figure with a ring-buckle belt and broad baldric appears on the well known ship relief from Palmyra, Syria. See M.A.R. Colledge, The Art of Palmyra (London 1976), Pl. 103; K. Tanabe, Sculptures of Palmyra I (Tokyo 1986), No. 430. Various frescoes found at Dura-Europos (Syria) and Castellum Dimmidi (Algeria) depict auxiliary soldiers in full colour. See S. James, The Excavations at Dura-Europos conducted by Yale University and the French Academy of Inscriptions and Letters, 1928 to 1937. Final Report VII. The Arms and Armour and other Military Equipment (London 2004), Pl. 1-4; C. Picard, Castellum Dimmidi (Paris 1949), Fig. 15-6. A graffito depicting a soldier with a long-sword, a large round chape and a broad baldric was found at Bu Ngem, Libya. See R. Rebuffat, 'Note sur le camp romain de Gholaia (Bu Ngem)', Libyan Studies 20 (1989), Fig. 5. To these may be added the 'seepage' of 3rd century military equipment into divine iconography, mainly belt and sword details, but sometimes also helmet and shield features. See for example E.J. Phillips, Corpus Signorum Imperii Romani, Great Britain I.1, Corbridge. Hadrian's Wall East of the North Tyne (Oxford 1977), No. 194; J.C.N. Coulston, 'A fragmentary altar to Jupiter from Wallsend', Archaeologia Aeliana ser. 5, 11 (1983), 309-313; S.R. Tufi, CSIR, Great Britain I.3, Yorkshire (Oxford 1983), No. 10; R.P. Wright and E.J. Phillips, Roman Inscribed and Sculptured Stones in Carlisle Museum (Carlisle 1975), No. 238; M. Henig, CSIR, Great Britain I.7, Roman Sculpture from the Cotswold Region, with Devon and Cornwall (Oxford 1993), No. 60; E. Éspérandieu, Recueil général des bas-reliefs, statues et bustes de la Gaule romaine (Paris 1907-1981), No. 4541, 5564, 7641; P. Filtzinger, Limesmuseum Aalen (Stuttgart 1971), Fig. 5; G. Piccottini, CSIR, Österreich II.1, Die Rundskulpturen von Virunum
} 
they may be used to study contemporary military dress and equipment in conjunction with documentary and artefactual sources. Whilst taking these considerations into account, it is the purpose of the present paper to go further by viewing the 3rd century AD group alongside the corpus of military funerary figures from the whole Roman period, thus allowing some holistic observations to be made about Roman military funerary practice and the presentation of Roman soldiers in death.

Third century, 'ring-buckle gravestones' were until fairly recently largely ignored in the English specialist literature, despite a significant number actually being found in Britain. ${ }^{4}$ In contrast, they have always been well recognised along the northern continental Roman frontiers, notably through the pioneering iconographic work of $\mathrm{Ubl}^{5}$ and the artefactual studies of Oldenstein. ${ }^{6}$ Three features of these particular monuments will be specifically investigated here: the military equipment, which is often depicted with great care to practical and accurate detail; the selective distribution of examples, as compared with earlier figural military gravestone types; and the political and cultural implications of the form and distribution of the funerary practice.

(Wien 1968), No. 21; L. Barkóczi, Brigetio, Dissertations Pannonicae ser. 2, 22 (Budapest 1944), Pl. LIX.6, LXV.2. See S. Von Schnurbein, 'Merkur als Soldat? Zur Gürtelmode des 3. Jahrhunderts n. Chr.,' in W. Czysz, ed., Provinzialrömische Forschungen. Festschrift für Günter Ulbert zum 65. Geburtstag (Espelkamp 1995), 139-148.

${ }^{4}$ Ignored by many general works on the Roman army, and by some specific studies, notably A.S. Anderson, Roman Military Tombstones (Aylesbury 1984). British examples: I.A. Richmond and R.P. Wright, Catalogue of the Roman Inscribed and Sculptured Stones in the Grosvenor Museum, Chester (Chester, 1955), No. 37, 125-126(?) (Chester); B.W. Cunliffe and M.G. Fulford, CSIR, Great Britain I.2, Bath and the Rest of Wessex (Oxford 1982), No. 47 (Bath); J.C.N. Coulston and E.J. Phillips, CSIR, Great Britain I.6, Hadrian's Wall West of the North Tyne, and Carlisle (Oxford 1988), No. 193 (Chesters); R.J. Brewer, CSIR, Great Britain I.5, Wales (Oxford, 1986), No. 19(?) (Caerleon); R.G. Collingwood and R.P. Wright, The Roman Inscriptions of Britain I, Inscriptions on Stone (Oxford 1965), No. 17; J. Wacher, The Towns of Roman Britain (London 1995), Fig. 36 (London). To these should be added Wright and Phillips 1975, op. cit. (n. 3), No. 226; J.G.N. Coulston, 'Two representations of 3rd century AD equipment from Cumbria', Arma 3.1 (1991), 2-5 (Brougham).

${ }^{5}$ H.-J. Ubl, Waffen und Uniform des römischen Heeres der Prinzipatsepoche nach den Grabreliefs Noricums und Pannoniens. Unpublished PhD thesis (Wien 1969).

${ }^{6}$ J. Oldenstein, 'Zur Ausrüstung römischer Auxiliareinheiten. Studien zu Beschlägen und Zierat an der Ausrüstung der römischen Auxiliareinheiten des obergermanischraetischen Limesgebietes aus dem zweiten und dritten Jahrhunderts n. Chr.', Bericht der römisch-germanischen Kommission 57 (1976), 49-284. 


\section{'Ring-buckle gravestones': dress and equipment}

The type of military representation takes its name from its most characteristic feature, a ring-buckle which fastens a broad waist-belt. This is the lineal descendant of the 1st century AD waist-belts for sword and/or dagger suspension with a long multi-strap 'apron'. ${ }^{7}$ The latter was shortened in the Flavian period and disappeared by the later 2nd century. The ring buckle belt was wrapped around the wearer's body and, once it had been passed through the ring-buckle and fastened with a stud, it was then looped up under the belt at the wearer's right side, before hanging down alongside the right leg. The belt-end was frequently bifurcated and bore a pair of metallic terminals. This whole assemblage required a considerable length of leather, approximately $2.0-2.3 \mathrm{~m}$. (90 in.), tailored and fastened to the individual's needs. The belt-end was not functional but for display. Indeed, unless a pugio was worn (these continue in the artefactual record, but are seldom depicted on 3rd century gravestones ${ }^{8}$ ) the whole belt served only to hold up the tunic hem in proper military fashion. The sword, long or short and worn from the late 2nd century on the soldier's left side, was suspended from a wide baldric which had its own purely decorative hanging strap-end with terminal metalwork, again delineated with care in the more detailed gravestone sculptures. ${ }^{9}$

The earliest diagnostic representation of a ring buckle belt may be on an altar from Eining (Germany), dated by consular nomenclature to $\mathrm{AD} 211 .{ }^{10}$ However, bifurcated belt-terminals were already a late $2 \mathrm{nd}$ century feature, as is suggested by the Lyon grave assemblage (a narrow 'VTERE FELIX' belt rather than a broad ring buckle belt here), ${ }^{11}$ and it may be that the ring buckle also appeared in the Late Antonine period. ${ }^{12}$ The end of its use is suggested by a lack of securely dateable

${ }^{7}$ M.C. Bishop and J.G.N. Coulston, Roman Military Equipment from the Punic Wars to the Fall of Rome (Oxford 2006, 2nd edition), 106-109, 182-184.

${ }^{8}$ Although see F. Wagner, CSIR Deutschland I.1, Raetia und Noricum (Bonn 1973), No. 29. For 3rd century pugiones see Bishop and Coulston 2006, op. cit. (n. 7), 164, Fig. 104.

${ }_{9}^{9}$ For 3rd century belts and bladed weapons see Oldenstein 1976, op. cit. (n. 6); Bishop and Coulston 2006, op. cit. (n. 7), 154-63, 182-84.

${ }_{10}$ Wagner 1973, op. cit. (n. 8), No. 477. However, S. von Schnurbein has cast serious doubt on the buckle identification: Von Schnurbein 1995, op. cit. (n. 3), n. 4.

${ }^{11}$ Bishop and Coulston 2006, op. cit. (n. 7), 163, Fig. 101.

${ }^{12}$ It might be postulated that mounted troops were the first to develop left-side, broad baldric suspension for the spathae they had been using since the 1st century. A parallel 
Tetrarchic ring buckle iconography. Undoubted ring buckles have been found in situ in funerary contexts, for example in graves at Regensburg (Germany) and Intercisa (Hungary), ${ }^{13}$ but they are generally less flat and broad of body than those depicted on gravestones. It is very likely that the size and shape of buckles was exaggerated by sculptors to give this characteristic item of military attire an emphasised prominence to catch the viewer's eye. This is what is seen in 1st-2nd century military representations, where attention is drawn to belt(s), apron and sword by applying a great deal of decorative detail, as on the 1st century Rhenish 'standing soldier' stelae ${ }^{14}$ by exaggerating the size of the sword, especially the pommel, as on 'rider' stelae, ${ }^{15}$ and/or by arranging the 1 st-2nd century paenula specifically to reveal these features. ${ }^{16}$

The stelae and other funerary representations continue some of the formulaic representation of soldiers seen in earlier centuries. The deceased may stand leaning on one or more shafted weapons, generally spears, occasionally short, light javelins or lanceae, but almost never pila outside Rome. The traditional form of legionary heavy javelins is largely confined to praetorian iconography in Rome. ${ }^{17}$ Many soldiers carry a shield or lean on a grounded shield. Boards are predominantly oval, ${ }^{18}$ the characteristic curved rectangular legionary shield not being represented in the iconography, despite its continued presence in the artefactual record. The shield might be entirely absent and be replaced

might be drawn with sword-suspension methods employed by European troopers in the 17th century: J. Tincey, Soldiers of the English Civil War (2). Cavalry (London 1990), 29.

${ }_{13}$ S. von Schnurbein, Das römische Gräberfeld von Regensburg (Kallmünz 1977), 88.

${ }^{14}$ For example Éspérandieu 1907-1981, op. cit. (n. 3), No. 5495, 5790, 5797, 5835, 5840, 5850, 5853, 6125, 6136-37, 8534; C. Franzoni, Habitus atque habitudo militis. Мonumenti funerari di militari nella Cisalpina Romana (Roma 1987), No. 24; M.C. Bishop, 'The early imperial 'apron", Journal of Roman Military Equipment Studies 3 (1992), Fig. 1-12.

${ }_{15}$ Notably Éspérandieu 1907-1981, op. cit. (n. 3), No. 6435; M. Schleiermacher, Römische Reitergrabsteine. Die kaiserzeitlichen Reliefs des triumphierenden Reiters (Bonn 1984), No. 17.

${ }^{16}$ E.g. A. Hofmann, Römische Militärgrabsteine der Donauländer (Wien 1905), Fig. 45, 48-9, 54-5; Éspérandieu 1907-1981, op. cit. (n. 3), No. 5798, 5840, 5853, 6207, $6252-53,6575$.

${ }_{17}^{17}$ J.C.N. Coulston, "Armed and belted men": the soldiery in imperial Rome', in J.G.N. Coulston and H. Dodge, eds., Ancient Rome: the Archaeology of the Eternal City. Oxford University Committee for Archaeology Monograph 54 (Oxford, 2000), 96-97. For a pilum carried by a beneficiarius on a funerary altar from Apamea, Syria, see J.-C. Balty, 'Apamea in Syria in the second and third centuries AD', Fournal of Roman Studies 78 (1988), Pl. XIV.1. For artefactual finds see Bishop and Coulston 2006, op. cit. (n. 7), 150.

${ }_{18}$ Corresponding with the dished, oval shields from Dura-Europos. See James 2004, op. cit. (n. 3), 176-182; Bishop and Coulston 2006, op. cit. (n. 7), 179. 
in the soldier's hand by a fustis. ${ }^{19}$ Alternatively, the man may hold a rotulus in his left hand and either be twirling his belt-strap in his right, or pouring a libation on an altar or thymiaterion by his side. Sometimes the long, dome-headed 3rd century version of the centurion's vitis, ${ }^{20}$ a military standard of some kind, ${ }^{21}$ or a musical instrument ${ }^{22}$ is figured to visually denote the soldier's rank. Very occasionally a helmet is carried or set by the man's feet, rarely is one worn..$^{23}$ Well sculpted examples correspond with the 'Heddernheim' helmet type which spread into use

19 M.P. Speidel, 'The fustis as a soldier's weapon', Antiquités Africaines 29 (1993), 137-149.

${ }^{20}$ H. Gabelmannn, Die Werkstattgruppen der oberitalischer Sarkophage (Bonn 1973), No. 112; Richmond and Wright 1955, op. cit. (n. 4), No. 37; C. Bossert-Radtke, CSIR, Scheiz, III. Die figürlichen Rundskulpturen und Reliefs aus Augst und Kaiseraugst (Augst 1992), No. 65; Barkóczi 1944, op. cit. (n. 3), Pl. XXIV.1; E. Pfuhl and H. Möbius, Die ostgriechischen Grabreliefs (Mainz 1977), No. 302-303.

${ }^{21}$ Franzoni 1987, op. cit. (n. 14), No. 5; Coulston and Phillips 1988, op. cit. (n. 4), No. 193; L. Eckhart, CSIR, Österreich III.2. Die Skulpturen des Stadtgebeites von Lauriacum (Wien 1976), No. 86; H. and H. Polenz, Das römische Budapest. Neue Ausgrabungen und Funde in Aquincum (Münster 1986), Fig. 28; Barkóczi 1944, op. cit. (n. 3), Pl. XXIV.1; L. Barkóczi, G. Erdélyi, E. Ferencszy, F. Fülep, J. Nemerskéri, M.R. Alföldi and K. Sagi, Intercisa I (Dunapentele-Sztalinvaros). Geschichte der Stadt in der Römerzeit (Budapest 1954), Pl. XXXVII.3; E. Maróti, Die römischen Steindenkmäler von Szentendre-Ulcisia Castra (Szentendre 2003), No. 54; M.P. Speidel, 'Eagle-bearer and trumpeter. The eagle-standard and trumpets of the Roman legions illustrated by three tomb-stones found at Byzantion', Bonner Fahrbücher 176 (1976), Fig. 1; Pfuhl and Möbius 1977, op. cit. (n. 20), No. 307; J.-G. Balty and W. van Rengen, Apamea in Syria. The Winter quarters of Legio II Parthica (Bruxelles 1992), Pl. 18; O. Stoll, 'Die Adler im 'Kafig'. Zu einer Aquilifer-Grabstele aus Apamea in Syrien', in O. Stoll, Römischer Heer und Gesellschaft. Gesammelte Beiträge 1991-1999. MAVORS 13 (Stuttgart 2001), 13-46; A. Bernand, Alexandria la Grande (Paris 1966), Fig. 14; L. Castiglione, 'Kunst und Gesellschaft im römischen Ägypten', Acta Antiqua Academiae Scientiarum Hungaricae 15 (1968), Pl. V.

${ }^{22}$ Hofmann 1905, op. cit. (n. 16), Fig. 56, 59; Speidel 1976, op. cit. (n. 21), Fig. 2, 9; Pfuhl and Möbius 1977, op. cit. (n. 20), No. 308; R. Meucci, 'Lo strumento del bucinator A. Surus e il cod. Pal. Lat. 909 di Vegezio,' Bonner Fahrbücher 187 (1987), 259-272.

23 A. Naumann, CSIR, Österreich I.1. Die Skulpturen des Stadtgebietes von Vindobona (Wien 1967), No. 27; M.L. Krüger, CSIR, Österreich I.3. Die Skulpturen des Stadtgebietes von Carnuntum 1 (Wien 1970), No. 320; Eckhart 1976, op. cit. (n. 21), No. 86; Barkóczi 1944, op. cit. (n. 3), Pl. VII.3, L.3; Richmond and Wright 1955, op. cit. (n. 4), No. 65; Pfuhl and Möbius 1977, op. cit. (n. 20), No. 308; Coulston and Phillips 1988, op. cit. (n. 4), No. 400; J.C.N. Coulston, 'Later Roman armour, 3rd-6th centuries AD', Fournal of Roman Military Equipment Studies 1 (1990), Fig. 1. To these may be added a helmeted figure from Linz (Austria) which has now been convincingly redated from the 4th to the 3rd centuries AD. See T. Fischer, 'Zu einer römischen Soldatendarstellung aus Lentia/Linz an der Donau', in K. Kuzmová, K. Pieta and J. Rajtár, eds., Zwischen Rom und dem Barbaricum. Festschrift fuir Titus Kolnik zum 70. Geburtstag (Nitra 2002), 89-96. 
by both infantry and cavalry in the 3rd century. ${ }^{24}$ Apart from helmet and shield, the soldier is almost always shown without armour. This implies nothing about the use and weight of body and limb armour in the 3rd century. Indeed, there are indications that armour became more extensive in its coverage during this period. ${ }^{25}$ The iconography simply continued the long existing tradition of showing men as they were normally seen outside the contexts of guard duty, review, training exercise and battle.

What the 3rd century pictorial record does show is a cultural shift away from traditional Mediterranean clothing styles, as represented on Trajan's Column and in 1st-2nd century funerary art, towards either northern European or Levantine fashions: from short-sleeved tunics and bare legs to long-sleeved tunics and long trousers. ${ }^{26}$ In terms of arms and armour, a continuous development of belt and baldric forms can be traced through the 1st to 4th century, but, most significantly, the equipment which distinguished the appearance and roles of legionary citizen troops from those of auxiliary peregrini, the 'lorica segmentata', the curved rectangular shield and the pilum, effectively disappear from the iconography. ${ }^{27}$

Third century figural gravestones and other funerary monuments have a peculiar distribution and marked concentrations across the Roman Empire. ${ }^{28}$ There are approximately 115 examples overall,

${ }^{24}$ H.R. Robinson, Armour of Imperial Rome (London 1975), Pl. 256-294; M. Feugère, Casques Antiques (Paris 1994), 117-120; Bishop and Coulston 2006, op. cit. (n. 7), 173-178.

${ }^{25}$ Coulston 1990, op. cit. (n. 23), 139-60; Bishop and Coulston 2006, op. cit. (n. 7), 170-173.

${ }^{26}$ Colledge 1976, op. cit. (n. 3), 48-51, 66-80, 98-100, 145-46; James 2004, op. cit. (n. 3), 246-47; G. Sumner, Roman Military Clothing 2, AD 200-400 (Oxford, 2003); Bishop and Coulston 2006, op. cit. (n. 7), 184. Long sleeves and long trousers are already worn by eastern(?) troops on the Column of Marcus Aurelius (Petersen et al. 1896, op. cit. (n. 1), Scenes XII, XV, XXVIII, XXXIX, LXXVIII).

${ }_{27}$ The 'lorica segmentata' is last seen in sculpture on the Arch of Severus, Forum Romanum, Rome, and on the Arch of Severus at Lepcis Magna (Brilliant 1967, op. cit. [n. 1], Pl. 46, 65, Fig. 98). Isolated finds of fittings may eventually take the armour form up to the later 3rd century (Bishop and Coulston 2006, op. cit. (n. 7), 171-173). The latest evidence for curved rectangular shields comes from mid 3rd century DuraEuropos. See James 2004, op. cit. (n. 3), 182-184; Bishop and Coulston 2006, op. cit. (n. 7), 180-182. Whilst the pilum is last seen on praetorian gravestones in Rome where it may have been a ceremonial survival (above, n. 17), pilum-like heavy javelins survived into the 4th century on the evidence of Vegetius, Epitome rei militaris I.20, II.15 (Bishop and Coulston 2006, op. cit. (n. 7), 200).

${ }^{28}$ Collected by Ubl 1969, op. cit. (n. 5); J.C.N. Coulston, 'Roman military equipment 
with the most occurring in Pannonia $(25-8)^{29}$ and in Rome $(23) \cdot{ }^{30}$ The area around Byzantion has 10, perhaps mainly representing deaths of soldiers marching back and forth between the eastern and Danubian fronts. ${ }^{31}$ Legionary troops are best represented in the corpus. Apamea,

on 3rd century AD tombstones', in M. Dawson, ed., Roman Military Equipment: the Accoutrements of War (Oxford 1987), 141-156; P. Noelke, 'Ein neuer Soldatengrabstein aus Köln', in C. Unz, ed., Studien zu den Militärgrenzen Roms III (Stuttgart 1986), 213-225. Whilst they are comparatively plentiful in Britain (n. 4, above), and on the Upper and Middle Danube (n. 29, below), only four 3rd century representations of soldiers occur along the Rhine: a gravestone at Köln (Noelke 1986); a mausoleum(?) relief (Landesmuseum Mainz, Inv. No. S1082, pers. obs.) and a relief on the side of an altar. See H. Cuppers, ed., Die Römer in Rheinland-Pfalz (Stuttgart 1990), Fig. 116 from Mainz; and a gravestone at Strasbourg (Éspérandieu 1907-1981, op. cit. (n. 3), No. 5507). They are equally scarce along the Lower Danube, just one relief occurring at Rusé in Bulgaria (pers. comm. Dr A. Poulter). Two funerary statues have been found at Alba Iulia (Alba Iulia Museum, pers. obs.) and two at Colonia Ulpia Sarmizegethusa (D. Alicu, C. Pop and V. Wollmann, Figural Monuments from Sarmizegethusa, Sarmizegethusa. Monograph 2, British Archaeological Reports, International Series 55 (Oxford 1979), No. 295, 297) in Dacia north of the Danube, and there are two statues in the Archaeological Museum, Sofia (pers. obs,). Examples also occur in Macedonia, well back from the frontier, at Thessalonike (incorporated in the east walls, pers. obs), Laskárevo (M. AlexandrescuVianu, 'Les steles funéraires de la Macédoine romaine', Dacia n.s. 19 (1975), No. 43, Fig. 2.2) and Veria (Bishop and Coulston 2006, op. cit. (n. 7), Fig. 111.2).

${ }_{29}$ Bossert-Radtke 1992, op. cit. (n. 20), No. 65; Wagner 1973, op. cit. (n. 8), No. 29, 31, 34, 350, 371; Hofmann 1905, op. cit. (n. 16), Fig. 56-9, 75, 97; H. Ubl, CSIR, Österreich I.6. Die Skulpturen des Stadtgebeites von Aelium Cetium (Wien 1979), No. 16; A.S. Burger, CSIR, Ungarn VII. Die Skulpturen des Stadtgebeites von Sopianae und des Gebietes zwischen der Drau und der Limesstrecke Lussonium-Altinum (Budapest 1991), No. 25, 33; Maróti 2003, op. cit. (n. 21), No. 54; Barkóczi 1944, op. cit. (n. 3), Pl. V.2, VII.3, X.2-3, XX.2, XXIII.1, XXIV.1, L.3; Polenz 1986, op. cit. (n. 21), Fig. 28; Barkóczi et al. 1954, op. cit. (n. 21), No. 32, 42, 130, 135, 220, 228; L. Barkóczi, 'Beiträge zur Steinbearbeitung in Pannonien am Ende des 3. Und zu Beginn des 4. Jahrhunderts', Folia Archaeologia 24 (1973), Fig. 1, 4, 14, 25; L. Barkóczi, 'Römerzeitliche Steindenkmäler aus dem dritten Jahrhundert im Komitat Fejér', Alba Regia 22 (1985), Fig. Pl. II, VI.

${ }^{30}$ P. von Bienkowski, 'Zur Tracht des römischen Heeres in der Spätrömischen Kaiserzeit', Fahrbuch des Österreichischen Archäologischen Instituts 19-20 (1919), Fig. 117-119; M. Durry, Les Cohortes Prétoriennes (Paris, 1938), Pl. X.B; L. Rocchetti, 'Su una stela del periodo tetrarchico', Annuario Scuola Archeologia di Atene 29-30 (1967-68), Fig. 1-2, 5-7; L. de Lachenal, B. Palma and M. Sapelli, eds., Museo Nazionale Romano, Le Scultore I.7.i. Catalogo delle sculture esposte nel giardino dei cinqucento (Roma 1984), No. V.20; S. Panciera, ed., La Collezione Epigraphica dei Musei Capitolini. Inediti, rivisioni, contributi al riordino 6 (Roma 1987), Pl. XVIII-IX; G. Gascou, 'Inscriptions de la ville de Rome et autres inscriptions italiennes conservées aux musées d'Aix-en-Provence, Carpentras, Avignon et Marseilles', Mélanges d'archéologie et d'histoire de l'École française de Rome, Antiquité (1988), No. 2; M.P. Speidel, 'Neckarschwaben (Suebi Nigrenses)', Archäologisches Korrespondenzblatt 20 (1990), 201-207; id., Die Denkmäler der Kaiserreiter equites singulares Augusti (Köln 1994), No. 535; E. Casamassima and R. Rubinstein, Antiquarian Drawings from Dosio's Roman Workshop. Biblioteca Nazionale Centrale de Firenze, N.A. 1159 (Milan 1993), No. 37a, 53, 56; Coulston 2000, op. cit. (n. 17), Fig. 5.3, 5.5, 5.17; Bishop and Coulston 2006, op. cit. (n. 7), Fig. 94.2, 4.

${ }^{31}$ Speidel 1976, op. cit. (n. 21); Pfuhl and Möbius 1977, op. cit. (n. 20), No. 303-305, 
as already mentioned, has a massive collection of 54 grave altars erected for II Parthica soldiers during that legion's repeated presence in the east during Severan campaigns. The environs of the legionary fortress at Nikopolis, near Alexandria in Egypt, has yielded up to 22 gravestones, mostly associated with the long-resident legio II Traiana fortis. ${ }^{32}$ Apart from those in the Greco-Roman Museum at Alexandria, others are scattered, in the usual manner of Egyptian antiquities, around the museums of Britain, Italy, Spain, Belgium and Poland.$^{33}$ All may be classed as standing soldier gravestones, with the exception of one rider stela, which has a well preserved paint scheme. ${ }^{34}$ Britannia has a scattering of $10-12$ ring buckle style representations as indigenous finds. ${ }^{35}$

Elsewhere they are markedly absent. Perhaps this is unsurprising for regions with comparatively few troops permanently present, as might

307-318. Similarly Aquileia, in its strategically pivotal position at the head of the Adriatic and close to the Alps, has a group of mainly Tetrarchic figural gravestones, but also with one ring-buckle stela (Museo Archeologico di Aquileia, Cataloghi dei Musei e Gallerie d'Italia (Roma 1972), No. 348-355; Franzoni 1987, op. cit. (n. 14), No. 12-21).

${ }_{32}$ G. Botti, Catalogue des Monuments exposés au Musée Gréco-Romaine d'Alexandrie (Alexandria 1900), No. 93-94; E. Breccia, Alexandria ad Aegyptum (Bergamo 1914), Fig. 41; G. Susini and R. Pincelli, Museo Civico, Bologna. Il Lapidario (Bologna 1960), Pl. XIX; Bernand 1966, op. cit. (n. 21), Fig. 13-15; Castiglione 1968, op. cit. (n. 21), Pl. V.1-2; A. Sadurska, Corpus Signorum Imperii Romani, Poland I.1. Les portraits romains dans les collections polonaises (Warszawa 1972), No. 55; K. Parlasca, 'Römisch-ägyptische Grabreliefs. Der aktuelle Stand eines Forschungsprojekts', in G. Pugliese Carratelli, G. del Re, N. Bonacasa and A. Etman, eds., Roma e l'Egitto nell'antichità Classica. Atti del I Congresso Internazionale Italo-Egiziano (Roma 1992), Fig. 4; A. Casanovas, ed., Scripta Manent. La Memòria Escrita dels Romans (Barcelona 2002), No. 131; H. Riad, Y.H. Shehati and Y. El-Gheriana, Alexandria. An Archaeological Guide to the City and the Graeco-Roman Museum (Cairo n.d.), Fig. 15. One mechanism which might account for this relatively isolated concentration may be the direct influence of troops, notably elements of legio II Parthica, present during Caracalla's visit to Alexandria (AD 215-16) and its associated military action (Dio 78.22-23; Herodian 4.9). See C. Bruun, 'Pericula Alexandrina: the adventures of a recently discovered centurion of legio II Parthica', Arctos 29 (1995), 9-27.

${ }^{33}$ Some finds were made by British forces at the Battle of Alexandria (March 21st, 1801), during which fighting raged through the standing ruins of Nikopolis. See W. Jackson, The Pomp of Yesterday. The Defence of India and the Suez Canal, 1798-1918 (London 1995), 23-25 and Map 3. These included the Severan inscription listing veterans of legio II Traiana (R.P. Wright, 'New readings of a Severan inscription from Nicopolis, near Alexandria', Fournal of Roman Studies 32 [1942], 33-38). The second time British forces were engaged in this theatre (1807) was perhaps less conducive to antiquities collection, a campaign not unconnected with the capture (1806) and the loss (1808) of Capri as a British possession (T. Pocock, Stopping Napoleon. War and Intrigue in the Mediterranean (London 2004), 20-22).

34 The writer is very grateful to Dr Katelijn Vandorpe, University of Leuven, for images and additional information about these gravestones. Dependent on funding, a proposed joint project between the Universities of St Andrews (Scotland) and Leuven (Belgium) will continue work on the corpus started by the late H. Devijver.

${ }_{35}$ See n. 4, above. 
be assumed for much of the Hispaniae, Galliae, Asiatic provinces and North Africa. Conversely, there was no shortage of troops in the Germaniae and Moesiae, but 3rd century figural gravestones are only present in these regions as isolated instances. This comparative absence may not be ascribed to regionally variant equipment practices. Indeed, the panoply seen on the gravestones seems to have been ubiquitous across the 3rd century empire, as is demonstrated not just by the gravestone figures but by the artefacts. Those studied by Oldenstein on the Upper German-Raetian frontier would not be out of place amongst those from Dura-Europos. ${ }^{36}$

Outside Rome, with its group of 'standing soldier' gravestones of praetorians, the majority of representations are of legionary soldiers. For auxiliary cavalry there continued to be the 'rider' type of stela, and banquet gravestones featuring a calo with a horse on long-reins, or a calo standing between horses remained in currency from earlier centuries. ${ }^{37}$ Indeed, in Rome calo scenes form the largest single type-group anywhere in the empire and at any time (89). ${ }^{38}$ Ring buckles appear most frequently and prominently on the midriffs of standing soldiers; sometimes they are shown worn by calones; sometimes by cavalrymen on horseback. ${ }^{39}$ These are mostly seen on gravestones, but at Apamea Syriae soldiers of legio II Parthica displayed a marked preference for grave-altars, as distinguished from cavalrymen who had stelae erected contemporaneously at the same site. ${ }^{40}$ Ring buckles also appear frequently worn by soldiers on 3rd century 'lion hunt' sarcophagi, ${ }^{41}$ and, less happily, by captured or submissive Roman emperors and soldiers on Sassanid Persian rock reliefs. ${ }^{42}$

${ }^{36}$ James 2004, op. cit. (n. 3), 240-241.

37 See n. 55, below.

${ }^{38}$ Speidel 1994, op. cit. (n. 30), No. 110-113, 127, 133-134, 137-138, 157-158, 164, 170, 189-190, 201-202, 205-208 etc. See A.W. Busch, 'Von der Provinz zum Zentrum - Bilder auf den Grabdenkmälern einer Elite-Einheit,' in P. Noelke, ed., Romanisierung versus Resistenz und Wiederaufleben einheimischer Elemente. Kolloquium Köln 2001 (Mainz 2001), 679-694.

${ }^{39}$ Speidel 1994, op. cit. (n. 30), No. 570, 598, 682.

${ }^{40}$ Balty 1992, op. cit. (n. 21), Pl. 20, 22, 24-26.

${ }^{41}$ B. Andreae, The Art of Rome (London 1977), Pl. 582-595; G. Koch and H. Sichtermann, Römische Sarkophage (München 1982), Pl. 79-92. S. von Schnurbein 1995, op. cit. (n. 3), 142-143, Fig. 2 is less convinced by a military identification, but the present author is persuaded by the context and other accompanying figures.

42 Together with diagnostic 3rd century sword and scabbard fittings: G. Herrmann, The Sasanian Rock Reliefs at Bishapur 1 (Berlin 1980), III, Fig. 4, Pl. 4, 6, 41-47; G. Herrmann, 


\section{Private figural military monuments: time and space}

In order to set the ring buckle depictions within a broader context it is necessary to review the whole corpus of Roman figural funerary representations. ${ }^{43} \mathrm{~A}$ collection of exclusively funerary representations of soldiers has been made, confined in the first instance to actual standing gravestones, but including other classes of monument for consideration. Occasionally figures of soldiers appear on larger mausolea, but in the style of gravestones, as with the group of cavalrymen on the Arlon monument (Gallia Belgica). ${ }^{44}$ Grave-markers in the form of altars instead of stelae were favoured by some 1 st-3rd century praetorians and 2nd century equites singulares Augusti in Rome, ${ }^{45}$ as by the $3 \mathrm{rd}$ century legionarii at Apamea. Standing soldiers representing the deceased and/or relatives appear on Pannonian sarcophagi (rather different from

The Sasanian Rock Reliefs at Bishapur 3 (Berlin, 1983), I, Fig. 1, Pl. 1, 5-6; II, Pl. 9, 12-13; G. Herrmann and D.N. Mackenzie, The Sasanian Rock Reliefs at Naqsh-i-Rustam, Naqshi-Rustam 6 (Berlin 1989), Fig. 1, Pl. 1-3, 6, 10-11.

${ }^{43}$ This was touched upon in J.C.N. Coulston, 'Military identity and personal selfidentity in the Roman army', in L. de Ligt, E.A. Hemelrijk and H.W. Singor, eds., Roman Rule and Civic Life: Local and Regional Perspectives. Proceedings of the Fourth Workshop of the International Network Impact of Empire (Roman Empire, 200 BC-AD 476), Leiden, June 25-28, 2003 (Amsterdam 2004), 135-152. Now the writer has a much clearer and more nuanced picture of the whole figural gravestone genre. The method of collection has been study of the major regional and museum catalogues, notably Hofmann 1905, op. cit. (n. 16); Éspérandieu 1907-1981, op. cit. (n. 3); A. Schöber, Die römische Grabsteine von Noricum und Pannonien (Wien 1923); S. Ferri, Arte Romana sul Danubio (Milano 1933); Barkóczi 1944, op. cit. (n. 3); Barkóczi et al. 1954, op. cit. (n. 21); Pfuhl and Möbius 1977, op. cit. (n. 20); N. Benseddik, Les troupes auxiliares de l'armée romaine en Mauretanie Césarienne sous le Haut-Empire (Algiers 1979); Schleiermacher 1984, op. cit. (n. 15); Franzoni 1987, op. cit. (n. 14); S.R. Tufi, Militari romani sul Reno (Roma 1988); Speidel 1994, op. cit. (n. 30); and in the Corpus Signorum Imperii Romani series. This has led to extensive fieldwork, which in turn has uncovered numerous unpublished items. For the record, the modern countries within the former Roman Empire which have not yet been visited are Belgium, Luxembourg, Portugal, Morocco, Algeria, and the Ukraine. Monuments of men above the rank of centurio are not directly considered in the present discussion. For these see H. Devijver, The Equestrian Officers of the Roman Army (Amsterdam 1989), 416-448; H. Devijver and F. van Wonterghem, 'The funerary monuments of equestrian officers of the Late Republic and Early Empire in Italy 50 вG-100 AD)', Ancient Society 21 (1990), 59-98.

${ }^{44}$ Éspérandieu 1907-1981, op. cit. (n. 3), No. 4022; H. Gabelmann, 'Römische Grabmonumente mit Reiterkampfszenen im Rheingebiet', Bonner Fahrbücher 173 (1973), 132-200.

45 De Lachenal et al. 1984, op. cit. (n. 30), No. V. 20; Speidel 1994, op. cit. (n. 30), No. 80, 83-6, 90; Coulston 2000, op. cit. (n. 17), Fig. 5.18. 
the generic hunt scenes of lion-hunt sarcophagi in Rome). ${ }^{46}$ Sometimes soldiers were carved on the tondo/medallion monuments of the Upper Danube region, ${ }^{47}$ or on the ends of the 'caisson' stones characteristic of Africa and Numidia. ${ }^{48}$ Soldiers appear as funerary statues in Pannonia and Dacia, ${ }^{49}$ and even amongst 1 st to 4 th century mummy-portraits from Egypt. ${ }^{50}$

Gravestones may first be defined by type of representation. Fullfigure or half-figure examples may be brought together as 'standing soldiers' ${ }^{51}$ Cavalrymen appear on 'rider' gravestones, including in this instance both the archetypal horseman-riding-down-barbarian, ${ }^{52}$ and the boar-hunt, 'Danubian Rider' scenes. ${ }^{53}$ Calo and horse panels might be further divided between those showing long-rein 'lunging' behind one horse,$^{54}$ and the man leading one horse or standing between two

${ }^{46}$ Hofmann 1905, op. cit. (n. 16), Fig. 59; Barkóczi 1944, op. cit. (n. 3), Pl. XX.2, XXIII.1, XXIV.1; Barkóczi et al. 1954, op. cit. (n. 21), Pl. LI.1, 2; Maróti 2003, op. cit. (n. 21), No. 54.

47 Hofmann 1905, op. cit. (n. 16), Fig. 29; Schöber 1923, op. cit. (n. 43), No. 336-337, 351.

${ }^{48}$ J. Baradéz, 'Fouilles de Tipasa', Libyca 2 (1954), Fig. 13-14; Benseddik 1979, op. cit. (n. 43), Fig. 27.

49 Barkóczi et al. 1954, op. cit. (n. 21), Pl. LXXI.4-5; D. Alicu, C. Pop and V. Wollmann, Figural Monuments from Sarmizegethusa, Sarmizegethusa Monograph 2, British Archaeological Reports, International Series 55 (Oxford 1979), No. 295, 297.

50 S. Walker and M. Bierbrier, Ancient Faces. Mummy Portraits from Roman Egypt (London 1997), No. 87-88; Das Museum für altägyptische Kunst in Luxor (Mainz 1981), No. 290.

51 See H. Gabelmann, 'Die Typen der römischen Grabstelen am Rhein', Bonner Jahrbücher 172 (1972), 65-140; Tufi 1988, op. cit. (n. 43).

${ }^{52}$ Conveniently, but not exhaustively collected by Schleiermacher 1984, op. cit. (n. 15). See M. Mackintosh, 'The sources of the horseman and fallen enemy motif on the tombstones of the western Roman empire', fournal of the British Archaeological Association 139 (1986), 1-21.

53 These are not so much derived from cultic motifs, where rider-gods commonly trample human figures under their horses' hooves (D. Tudor, Corpus Monumentorum Religionis Equitum Danuviorum I. The Monuments. Études preliminaries aux religions orientales dans l'empire romain 13.1 (Leiden, 1969), No. 1-3, 6, 9, 16-20, 23-3 etc., although see No. 90), but from eastern Hellenistic funerary models featuring all or some of horseman, dog, cave with emerging boar, and tree with entwined serpent (G. Bordenache, 'Temi e motivi della plastica funeraria di età Romana nella Moesia Inferior', Dacia n.s. 9 (1965), Fig. 10-2, 17-8, 20, 26; Pfuhl and Möbius 1977, op. cit. (n. 20), No. 1402-1403, 1408, 1410, 1412-1413). Cf. M. Speidel, Die Equites Singulares Augusti. Begleittruppe der römischen Kaiser des zweiten und dritten Jahrhunderts (Bonn 1965), 79-83; id. 1994, op. cit. (n. 30), No. 109, 136, 258, 363, 525, 541, 543-544, 579, 584(?), 591-600, 604, 682.

54 Espérandieu 1907-1981, op. cit. (n. 3), No. 5838, 6448, 6454-6455, 6460, 6463, $6465,6589$. 
led horses. ${ }^{55}$ The former may have had Rhenish origins whilst the latter may have been a specifically Danubian motif, and both spread to Rome and elsewhere. ${ }^{56}$ These may be further defined by date based on the evidence of location (finds from Hadrian's Wall or Dacia must be after the 1 st century $\mathrm{AD}$ ), form of depiction and types of equipment (e.g. 1st century belt decoration; Tetrarchic Pannonian headwear), epigraphic considerations (consular date, unit title histories, personal names etc.), and artistic style (scene genres, decorative comparanda etc.). Often this involves pieces which cannot be tied down directly to one century.

Thus an approximate total of 620 gravestone representations date from the Late Republic to the 4th century AD. Adding the other classes of funerary iconography forms a corpus of approximately 742 items. ${ }^{57}$ Although this figure is not as large as for the extraordinary corpus of 5th-4th century BC Attic grave stelai ${ }^{58}$ it is considerable by any preEarly Modern standard. Moreover, the individual Roman pieces are vastly more varied and informative in composition and content than the Greek items.

${ }^{55}$ E.g. Hofmann 1905, op. cit. (n. 16), Fig. 18, 25, 42-46, 63-64; Schöber 1923, op. cit. (n. 43), No. 54, 58, 190, 192, 255, 259; Barkóczi 1944, op. cit. (n. 3), PL. VI.3; Barkóczi et al. 1954, op. cit. (n. 21), Pl. XXXV.2, XXXVI.1, LXI.5.

${ }_{56}$ Busch 2001, op. cit. (n. 38).

57 These figures represent bare minima based on what the writer has collected from publications and through independent fieldwork. With the best will and industry in the world they cannot possibly be exhaustive for the simple reasons that not all publications have been obtained, many unpublished items lurk within and without museum collections, and new pieces are discovered every year. In 2005 a gravestone of an armed and armoured classiarius was found at Classe, Italy (http://archeobo. arti.beniculturali.it/comunicati stampa/stele clasen.htm; viewed 25.01.06). A cavalry gravestone found at Lancaster, England, depicts a horseman carrying the severed head of the barbarian below (http://www. 10000things.org.uk/cityoflancaster.htm; viewed 25.01.06). The latter is relevant to an earlier discussion in this Impact of Empire series (J.C.N. Coulston, 'Overcoming the barbarian. Depictions of Rome's enemies in Trajanic Monumental art', in L. de Blois, P. Erdkamp, O. Hekster, G. de Kleijn and S. Mols, eds., The Representation and Perception of Roman Imperial Power. Proceedings of the Third Workshop of the International Network Impact of Empire [Roman Empire, 200 BC-AD 476], Rome, March 20-23, 2002 (Amsterdam 2003), 404-408). See also G.D. Stiebel, 'Scalping in Roman Palestine-“minime Romanum sacrum"?,' Scripta Classica Israelica 24 (2005), 151-162).

${ }^{58} 2361$ examples considered by R. Osborne, 'Law, the democratic citizen and the representation of women in classical Athens', Past and Present 155 (1997), 3-33 = R. Osborne, ed., Studies in Ancient Greek and Roman Society (Cambridge 2004), 38-60, based on C.W. Clairmont, Classical Attic Tombstones (Kilchberg 1993). It would be interesting to be able to compare the total of full-size, knightly, stone effigies known from the area of the former Roman Empire, for the 12th-15th centuries AD. 
Overall the gravestones break down into 264 standing soldier type (SS); 236 rider type $(\mathrm{R}) ; 123$ calo and horse reliefs $(\mathrm{CH})$. The overall difference in numbers between standing soldier and rider gravestones is not proportionally very large, whilst the number of calo and horse stelae is surprisingly high, and this is due to the figures from Rome (two-thirds of the overall total).

For standing soldier reliefs the numbers break down chronologically as follows: 136 for the 1st-2nd centuries (SS1-2); 115 for the 3rd century (SS3); 14 for the 4th century (SS4). Again, the comparative numbers of 1 st-2nd and 3rd century standing soldier gravestones seems well balanced (presence or absence of a paenula is a useful quick-reference dating feature), but in fact the second figure is spread over half the time of the first, and adjusting them would give comparative figures of 136 and 230 (or 68 and 115). One should in addition perhaps include the grave-altars from Apamea, but also those from Rome and elsewhere, plus funerary statues. Thus: $136+8: 115+56$ (altars) +7 (statues) or 72:178. Although these figures might be offset by high survival rates in large cemeteries and long-standing antiquarian collections in Rome, plus the increased size of the 3rd century army, still the suggestion is of a higher rate of erection in the 3rd century. The small, 'long' 4th century total, from the Tetrarchy onwards, is indicative of the general downturn in sculpture and epigraphy.

For rider gravestones the numbers break down chronologically as follows: 139 for the 1st-2nd centuries (R1-2); 22 for the 2nd-3rd century (R2-3); 60 for the 3rd century (R3); 4 for the 3rd-4th century (R3-4); and 11 for the 4th century (R4). Rider gravestones are less easy to date definitively, hence the wide overlaps, but if the R2/3 category is evenly split, this gives an approximate 2:1 ratio, predictable if the class of stela was erected at an even rate over three centuries.

For calo and horse reliefs the numbers break down chronologically as follows: 9 for the 1st century $(\mathrm{CH} 1) ; 37$ for the 2nd century $(\mathrm{CH} 2) ; 18$ for the 1st-2nd centuries (CH1-2); 22 for the 3rd century (CH3); and 37 for the 2nd-3rd centuries (CH2-3). The 123-strong calo and horse group is inflated and dominated by Rome (89), and to a lesser extent by the Germaniae (13) and Pannonia (16). On balance it seems that the type originated in the Rhineland and enjoyed a slightly later and stylistically separate development on the Danube, spreading to Rome from both regions in the 2nd century.

If we now examine gravestones sorted by type and by province/location we see the following distributions: 


\section{Roma}

SS1-2 $\quad 10$

SS3 $\quad 13$

$\mathrm{SSH} 3 \quad 10$

$\mathrm{R} \quad 34$

$\mathrm{CH} \quad 89$

\section{Britannia}

$\begin{array}{ll}\text { SS1-2 } & 17 \\ \text { SS3 } & 10-12 \\ \text { R } & 19\end{array}$

\section{Germania Inferior}

SS1

20

SS1-2

5

$\mathrm{SSH} 1$

1

SS3

2

R1

39

R1-2

CH1

8

\section{Germania Superior}

SS 1

12

SS1-2

3

SS3

1

$\mathrm{R} 1$

2

R1-2 12

CH1 1

CH1-2 4

\section{Pannonia}

SS1-2 15

SS3 24

SSH3 1

SS2-3 3

R1 4

R2 6

R1-2 17

R3 3

CH1-2 7

CH2-3 6

CH3 3


Rome has a high 3rd century representation, commensurate with the Severan expansion of military formations in the city, but also reflecting the Danubian shift in praetorian recruitment. ${ }^{59} \mathrm{~A}$ high cavalry-linked contingent reflects the provincial recruitment of equites singulares Augusti. ${ }^{60}$ In Britain troops favoured standing soldier stones, well represented over two and a half centuries (rather than three, with a late, half-century start after $\mathrm{AD} 43$ ), but there was also a strong and continuing rider gravestone tradition, brought over in $\mathrm{AD} 43$ from the Rhineland, and reflecting the self-regard of auxiliary cavalry. ${ }^{61}$ Likewise in the Rhineland standing soldier stelae had an early, particularly pre-Flavian currency, and the auxiliary cavalry were even more prominent than in Britain. ${ }^{62}$ Lastly, in Pannonia, 3rd century standing soldiers predominated, but in the earlier period rider gravestones were strongly represented. ${ }^{63}$

\section{'Ring buckle gravestones': concentrations and implications}

Any study of gravestones comes with the customary series of health warnings. In the Roman corpus there are obvious biases towards wealth and rank, statistics skewed by patterns of survival, collectability and modern recording. ${ }^{64}$ Above all it must be realised that these gravestones, however arresting and immediate they are in presenting the images of deceased soldiers, probably represent a small proportion of those which were originally sculpted and erected. Some 740 images certainly constitute a tiny sample of the bare minimum of five and a quarter million Roman soldiers who served over 350 years. ${ }^{65}$ The fortuitous discovery of

\footnotetext{
59 A. Passerini, Le Coorti Pretorie (Rome 1939), 171-183; Coulston 2000, op. cit. (n. 17), 91, 99.

${ }^{60}$ Speidel 1965, op. cit. (n. 53), 16-21; M.P. Speidel, Riding for Caesar. The Roman Emperors' Horse Guard (London 1994), 38-41, 81-86.

${ }^{61}$ Continuing through to the 3rd century (Schleiermacher 1984, op. cit. (n. 15), No. 68, 71, 73, 80, 82-83).

${ }^{62}$ Schleiermacher 1984, op. cit. (n. 15), No. 4-48, 51-52.

${ }^{63}$ Schleiermacher 1984, op. cit. (n. 15), No. 84, 87, 98, 111-115, 127-134.

${ }^{64}$ In general see W. Scheidel, Measuring Age, Sex and Death in the Roman Empire. Explorations in Roman Demography. Journal of Roman Archaeology Supplement 21 (Ann Arbor 1996), 97-138; G. Oliver, 'An introduction to the epigraphy of death: funerary inscriptions as evidence', in G.J. Oliver, ed., The Epigraphy of Death. Studies in the History and Society of Greece and Rome (Liverpool 2000), 1-19.

65 The most approximate and hasty of calculations: average of 30 legiones (exaggerated to cover guard and fleet units and army growth) of 5000 men, doubled (to include auxilia), multiplied by the period (350 years) divided by length of service (arbitrary 20
} 
stelae and grave altars at Apamea demonstrates this nicely. Finds made at just one site constitute almost 10\% of the whole corpus!

The exercise in statistical study already introduced is limited in very many ways, but it is still possible to tentatively explore some factors generating the crudely delineated patterns.

Elsewhere it has been suggested that the praetorians in Rome sought to emphasise their identity as an alien and sometimes alienated community through their funerary art. ${ }^{66}$ This was not so much an issue whilst the cohortes praetoriae were predominantly recruited from Italians, but the influx of provincial legionarii for the Guard post AD 193 injected a new demographic element which may have felt culturally intimidated by the metropolis. There were undoubted tensions between praetoriani and the plebs sordidus which perennially erupted in major rioting. ${ }^{67}$ Funerary inscriptions tend to emphasise Danubian birth, whilst Danubian forms of gravestone iconography came to prominence. From the early 2nd century the equites singulares Augusti were already in a similar position, socially as well as culturally apart from the urban population, and at times equally at odds with the masses. ${ }^{68}$ During the Julio-Claudian period the corporis custodes Germanici adopted the same form and decoration for their gravestones as used by the praetorians, a striking form of acculturation perhaps designed to make a statement about competitive status within the bodyguard formations. ${ }^{69}$ Might not an element of competition be reflected in the 3rd century gravestones? The most splendid figural examples indeed were put up for singulares, most of the praetorian instances being much smaller stones. After AD 212 theoretically the two bodies of troops possessed similar citizen status, but this would not have lessened competition. Perhaps it even heightened it?

years $)$, or $(30 \times 5000) \times(350 / 20)=5,250,000$. The real number of individuals passing through the formations would have been much larger, reflecting deaths in service.

${ }^{66}$ Coulston 2000, op. cit. (n. 17), 96. See K. Hopkins, Death and Renewal (Cambridge 1983), 213-214; D. Noy, Foreigners at Rome. Citizens and Strangers (London 2000), 218-220; A.W. Busch, 'Kamaraden bis in den Tod? Zur militärischen Sepulkraltopographie im kaiserzeitlichen Rom', in P. Zanker, R. Neudecker and V. Kockel, eds., Lebenswelten, Bilder, Räume. Symposium Rom, 2002, Palilia 13 (forthcoming).

${ }^{67}$ Dio 74.16; Herodian 7.11-12; SHA, Maximus et Balbinus 10.4-8. See J. Curran, Pagan City and Christian Capital. Rome in the Fourth Century (Oxford 2000), 26-35.

${ }^{68}$ Dio 73.13; Herodian 1.12.6-9.

${ }^{69}$ H. Bellen, Die Leibwache der römischen Kaiser des julisch-claudischen Hauses (Wiesbaden 1981), 62-63, Pl. IV-X; A. Giuliano, ed., Museo Nazionale Romano. Le Sculture I.7.1. Catalogo delle sculture esposte nel giardino cinquecento (Roma 1984), No. IV.29a-d; Coulston 2000, op. cit. (n. 17), 96, Fig. 5.4. 
Both formations were quite capable of fighting on opposite sides during rioting, spectacularly from Commodus' principate onwards.

On the frontiers there will have been other, less well documented rivalries. Certainly legionarii resented and despised the easy lives of overpaid and under-worked praetoriani, ${ }^{70}$ but what about relations between legionarii and auxiliarii? The very fine group of Julio-Claudian stelae at Bad Kreuznach entirely represents auxiliary milites gregarii, yet exactly the same care was taken with prominent swords, daggers and belts as on legionary gravestones at nearby Koblenz and Mainz. ${ }^{71}$ Were the deceased and/or their heirs claiming equality of honour and status with citizen troops?

Rider gravestones may be viewed in a similar light. In the 1st century $\mathrm{AD}$ they were the reserve of wealthy cavalrymen, non-citizens for the most part, but often with elevated status within their own societies and cultures. Some Rhenish tribal rider-élites were buried with their horses and/or military attire, and used their equipment in votive ritual..$^{72}$ Thracian rider-élites were buried with their horses and equipment in steppe nomad style kurgans $^{73}$ Less wealthy, yet status conscious cavalrymen, and their heirs, used figural rider gravestones to advertise mounted dominance, large and richly carved stelae distinguishing the men from

70 Notably Tacitus, Historiae 2.21.

${ }^{71}$ Bad Kreuznach: Éspérandieu 1907-1981, op. cit. (n. 3), No. 6125, 6136-6137. Mainz \& Koblenz: ibid., No. 5790, 5797, 5835, 5853, 8534. See V. Hope, 'Inscriptions and sculpture: the construction of identity in the military tombstones of Roman Mainz,' in G.J. Oliver, ed., The Epigraphy of Death. Studies in the History and Society of Greece and Rome (Liverpool 2000), 155-185. The close links between the unusually prominent cohors mill. I Hemesenorum sag. eq. c.R. at Intercisa and nearby legions, especially legio II Adiutrix at Aquincum are also reflected in the use in common of 3rd century figural sarcophagi (J. Fitz, Les Syriens à Intercisa (Bruxelles 1972), 160; see n. 46, above).

${ }^{72}$ H.L.H. van Enckevort and W.J.H. Willems, 'Roman cavalry helmets in ritual hoards from the Kops Plateau at Nijmegen, the Netherlands', fournal of Roman Military Equipment Studies 5 (1994), 125-154; J.A. Waasdorp, Van Romeinse Soldaten en Cananefaten (Den Haag, 1999); C. van Driel-Murray, 'Wapentuig voor Hercules', in N. Roymans and T. Derks, eds., De tempel van Empel (s'Hertogenbosch 1994), 92-107. In general see C. van Driel-Murray, 'Ethnic soldiers: the experience of the Lower Rhine tribes', in T. Grünewald and S. Seibel, ed., Kontinuität und Diskontinuität. Germania inferior am Beginn und am Ende der römischen Herrschaft (Berlin 2003), 200-217.

${ }^{73}$ E.g. I. Velkov, 'Neue Grabhügel aus Bulgarien', Bulletin de l'Institut d'Archéologie Bulgare 5 (1928-1929), 13-55; A.M. Mansel, 'Grabhügelforschung in Ostthrakien', Bulletin de l'Institut d'Archéologie Bulgare 12 (1938), 154-189; H. Bujukliev, La Nécropole Tumulaire de Catalka, Region de Stara Zagora (Sofia 1986), elements of the rite being transferred away from the Danube region, cf. S. Abdul-Hak, 'Rapport préliminaire sur les objets provenant de la nécropole romaine située a proximité de Nawa (Hauran)', Les Annales Archéologiques de Syrie 4-5 (1954-1955), 163-188. 
citizen legionaries and lower status auxiliary infantry. In all periods the horse has been used as a symbol of power and social standing, and sometimes even praetorian and legionary cavalrymen adopted the 'triumphal rider' motif to distinguish themselves from their commilitones on foot. ${ }^{74}$ Thus in some respects these patrons of rider gravestones were on the frontier, literally, between native elite status and Roman cultural/funerary practice.

In the 3rd century the Constitutio Antoniniana widened citizenship, or at least confirmed demographic trends long since underway, and the theoretical status of different formations converged. As has already been observed, in the same period the forms of military equipment which had traditionally distinguished legionary from auxiliary battlefield roles lost their prominence, meaning that all troops could take on a similarly wide series of functions. Although it is clear that legionary vexillationes were detached from parent legions throughout the Principate, as the period progressed the rump legions became more sedentary, and in the 3rd century vexillationes of one or two cohorts travelled the empire, sometimes never to return to their parent formations. ${ }^{75}$ Meanwhile, auxiliary regiments developed new skills in construction and manufacture, once the preserve of the old large legions packed with technicians. ${ }^{76}$ Thus legionary service was increasingly indistinguishable from auxiliary activities, a background against which there may actually have been a need to advertise legionary identity as a continuing, high kudos status.

Inscriptions which celebrate Concordia between legionary vexillationes may be interpreted by cynics as patching up relations after a quarrel, a sort of post bar-fight scenario. ${ }^{77}$ On the other hand, they may be seen as marking celebrations of mutual identity, re-affirmations of status and legionary brotherhood in a world of isolation from parent legions, of arriviste auxiliaries and of increasingly threatening barbarians. Renewed emphasis on legionary emblems seems to be part of

\footnotetext{
${ }^{74}$ Equites praetoriani: Coulston 2000, op. cit. (n. 17), Fig. 5.3. Equites legionis: Schleiermacher 1984, op. cit. (n. 15), No. 4, 70, 86, 98, 107, 114, 120.

${ }^{75}$ R. Saxer, Untersuchungen zu den Vexillationen des römischen Kaiserheeres von Augustus bis Diokletian (Köln 1967). Cf. RIB 334 (Caerleon).

${ }^{76}$ In Britain auxiliaries were already stamping tiles from the Trajanic-Hadrianic period $(R I B 2469,2472)$ and eastern auxiliaries were first building in stone at Carvoran from the time of Hadrian $(R I B$ 1808, 1810, 1818, 1820, linked with 1778).

${ }^{77}$ For example RIB 1125 (Corbridge); M.W.C. Hassall and R.S.O. Tomlin, 'Roman Britain in 1988 II. Inscriptions', Britannia 20 (1989), No. 4-5 (Carlisle). See discussion in R.S.O. Tomlin, 'A Roman altar from Carlisle Castle', Transactions of the Cumberland and Westmoreland Antiquarian and Archaeological Society 89 (1989), 86-88.
} 
this process and their potency was still great enough for a Carausius in the late 3rd century to place such totems on numismatic appeals to the troops. ${ }^{78}$ There are many examples in more recent armies where social cachet has been a potent force denoting status and fostering élan in formations, yet without their having distinctive military equipment for a specific battlefield role. The French kings' Maison du Roi, Napoléon's Garde Impériale, or the Guard regiments of the Victorian British army are cases in point. ${ }^{79}$ Of course their uniforms, insignia and standards identified them to the professional observer, as did shield-blazons, crests and standards in the Roman context. ${ }^{80}$ Stripped as they were of their integral cavalry, archers, light infantry and artillery, the legions of the Late Roman army still formed many of the 'senior' units, as shown by listings in the Notitia Dignitatum. ${ }^{81}$

Thus the legionary domination of the 3rd century standing soldier genre may be observed as one method of maintaining and advertising superior status within a larger and more homogenous army. Likewise, the use of imperial portraiture traits on 'private' gravestones ${ }^{82}$ perhaps

${ }^{78}$ J. Casey, Carausius and Allectus: the British Usurpers (London 1994), 92-96.

79 A nice case in point is provided by the Battle of the Alma (September 20th, 1854) when the Grenadier Guards rejected an offer for a lower status formation to advance with them and support their open flank, despite dire tactical need, purely as a mark of their own precedence. As Kinglake described it: "Around these two standards General Codrington rallied such men as he could gather, and made them open out and form line two deep. The body thus formed numbered about 300 men, and General Codrington wished to place it on the left of the Grenadiers, in order to fill a part of the chasm at that moment lying quite open in the centre of the Brigade of Guards. But it occurred to him - for he was himself a Guardsman, and he knew the feelings of the corps - that to place soldiers of the line abreast of the Grenadiers, and in the room of the broken regiment, might give pain to a battalion of the Guards: so he went to the Grenadiers to know if they would like troops to come up to fill the empty space. The answer was a proud one. It was also a rash answer ... However, the answer was 'No!' and the Grenadiers, with their left flank stark open, but in beautiful order, contentedly marched up the slope" (A.W. Kinglake, The Invasion of the Crimea. Its Origin and an Account of its Progress down to the Death of Lord Raglan (Edinburgh/London, 1901), 3, 221-222).

${ }^{80}$ Coulston 2004, op. cit. (n. 43), 137-138, 146-147.

${ }^{81}$ Generally ordered after the cavalry vexillationes but before the auxilia palatinae in the field armies, and above the old auxilia in the lists of frontier troops (Notitia Dignitatum, Oriens V.41-47, VI.41-47, VII.38-47, VIII.33-53, IX.30-38, XXVIII.14-19, XXIX.7-8, XXXI.31-39, XXXII.30-31, XXXIII.28, XXXIV.30, XXXV.24, XXXVI.29-30, XXXVII.21-22, XXXVIII.13-16, XL.29-36, XLII.30-39; Occidens V.141-156, XXXII.44-48, XXXIII.51-57, XXXIV.25-27, 37-41, XXXV.17-22, XL.18, XLII.26).

${ }^{82}$ Cf. E.J. Phillips, 'The gravestone of M. Favonius Facilis at Colchester', Britannia 6 (1975), 104 (Claudius); Speidel 1990, op. cit. (n. 30), 202, Pl. 23 (Caracalla). 
denoted not so much loyalty to one particular emperor (although Caracalla was the soldiers' emperor par excellence!), so much as solidarity with an army identity and ethos of service. However, this was not the entire picture, otherwise why did not all legionary installations in all provinces have halos of 3rd century figural gravestones around them? The answer comes from the other dominant variable, differences in regional funerary practice. The Rhenish army did not erect stelae at this time, whilst the Pannonian army did. Recruitment of Illyriciani spread the practice to Rome, where it was amplified for specific local cultural reasons, and outwards again with movements of troops to take part in major imperial campaigns. Danubian stelae are also distinguished by a marked emphasis on family members within a hierarchy, children and not just a female partner frequently appearing as groups on 3rd century tombstones, the soldiers carefully distinguished from other males by their equipment. ${ }^{83}$ Does this show some sociological trend at work in this region? Perhaps the spread of the ring buckle panoply, most likely initiated in the Upper/Middle Danube zone together with other technical innovations, was, like the funerary practice, a feature of the Illyrian military 'renaissance.' When the Rhineland forces were strategically and numerically dominant this was the golden age of Rhenish figural gravestones. Likewise, the predominance of the Danubians went hand in hand with the outburst of 3 rd century figural gravestones. ${ }^{84}$

${ }^{83}$ For example Hofmann 1905, op. cit. (n. 16), Fig. 58; Schöber 1923, op. cit. (n. 43), No. 154, 158, 198, 216, 239, 261; Barkóczi 1944, op. cit. (n. 3), Pl. VII.2, X; id. 1973, op. cit. (n. 29), Fig. 1, 3-4; id. 1985, op. cit. (n. 29), Pl. II, VI, VII.1, X.2; Barkóczi et al. 1954, op. cit. (n. 21), Pl. XXXVII.1.

${ }^{84}$ For further discussions of military identity, especially in the contexts of funerary art and military equipment, see V.M. Hope, 'Words and pictures: the interpretation of Romano-British tombstones', Britannia 28 (1997), 246-258; id. 2000, op. cit. (n. 71); V.M. Hope, Constructing Identity: the Roman Funerary Monuments of Aquileia, Mainz and Nîmes. British Archaeological Reports International Series 960 (Oxford 2001); S. James, 'The community of the soldiers: a major identity and centre of power in the Roman empire,' in P. Baker, S. Jundi and R. Witcher, eds., TRAC 98. Proceedings of the Eighth Annual Theoretical Roman Archaeology Conference, Leicester, 1998 (Oxford 1999), 14-25; J. Obmann, 'Waffen - Stauszeichen oder altäglicher Gebrauchsgegenstand?,' in H. von Hesberg, ed., Das Militär als Kulturträger in römischer Zeit (Köln 1999), 189-200; A. Gardner, 'Identities in the Late Roman Army: material and textual perspectives,' in G. Fincham, G. Harrison, R. Holland and L. Revell, eds., TRAC 2000. Proceedings of the Tenth Annual Theoretical Roman Archaeology Conference (Oxford 2001), 35-47; O. Stoll, "De honore certabant et dignitate". Truppe und Selbstidentifikation in der Armee der römischen Kaiserzeit', in O. Stoll, Römisches Heer und Gesellschaft. Gesammelte Beiträge 1991-1999 (Stuttgart 2001), 106-136; G. Alföldy, 'Kaiser, Heer und soziale Mobilität im römischen Reich', in A. Chaniotis and P. Ducrey, eds., Army and Power in the Ancient World (Stuttgart 2002), 123-150; Coulston 2004, op. cit. (n. 43). 


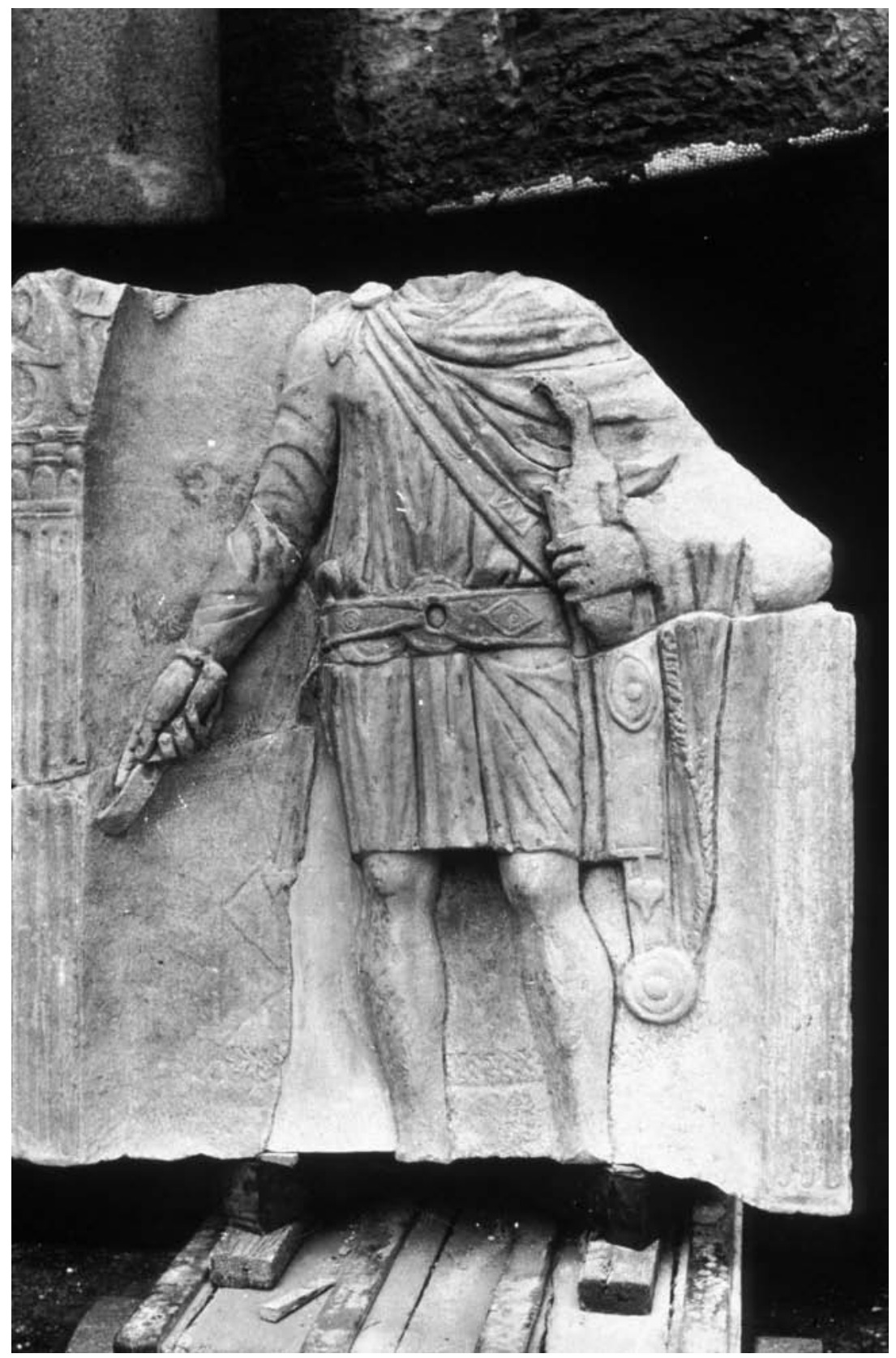

Fig. 1. Third century gravestone of an unknown praetorianus. Museo Nazionale delle Terme, Rome, Italy. Photograph: Museo Nazionale. 


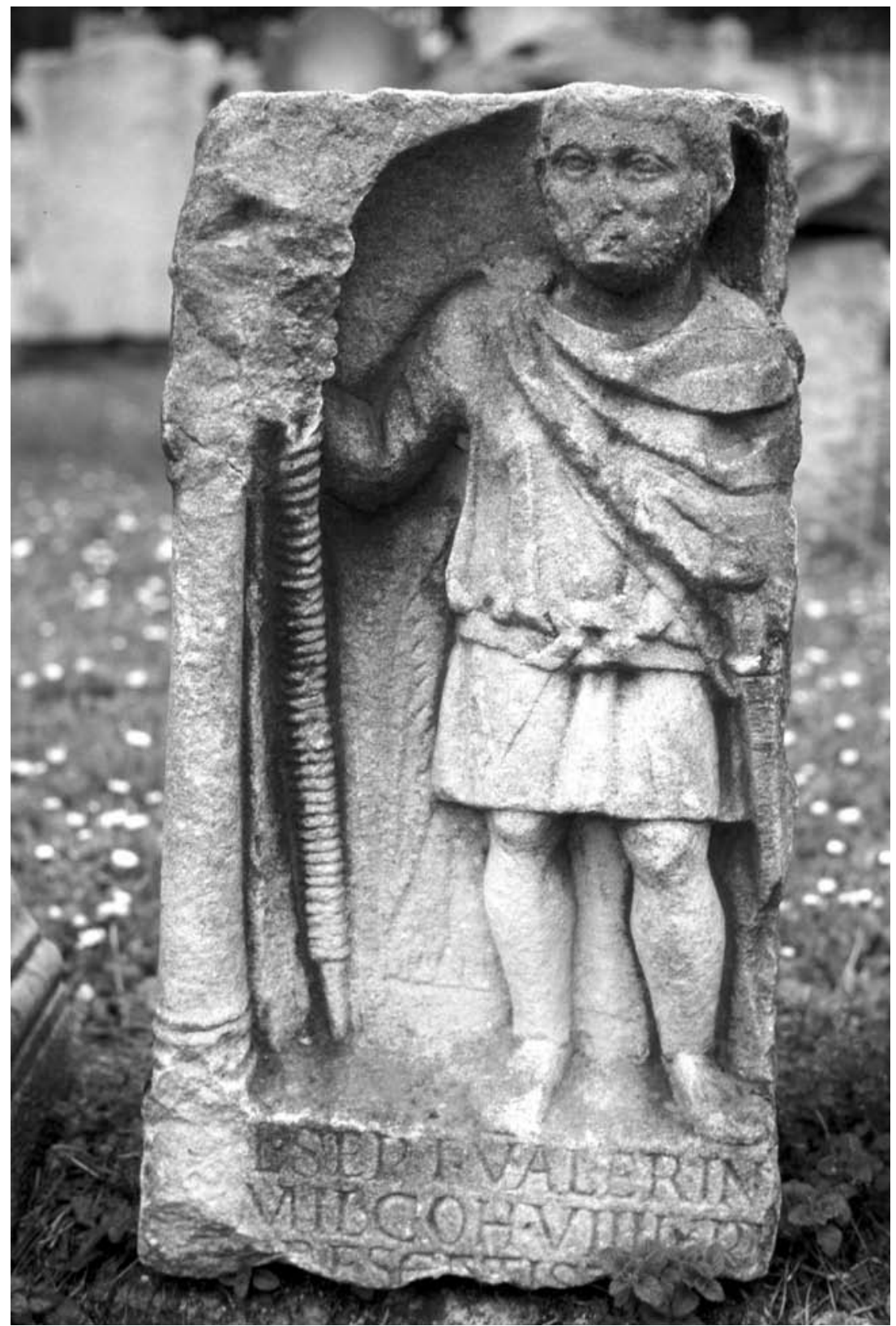

Fig. 2. Third century gravestone of praetorianus L. Septimius Valerinus. Museo Nazionale delle Terme, Rome, Italy. Photo: J.C.N. Coulston. 


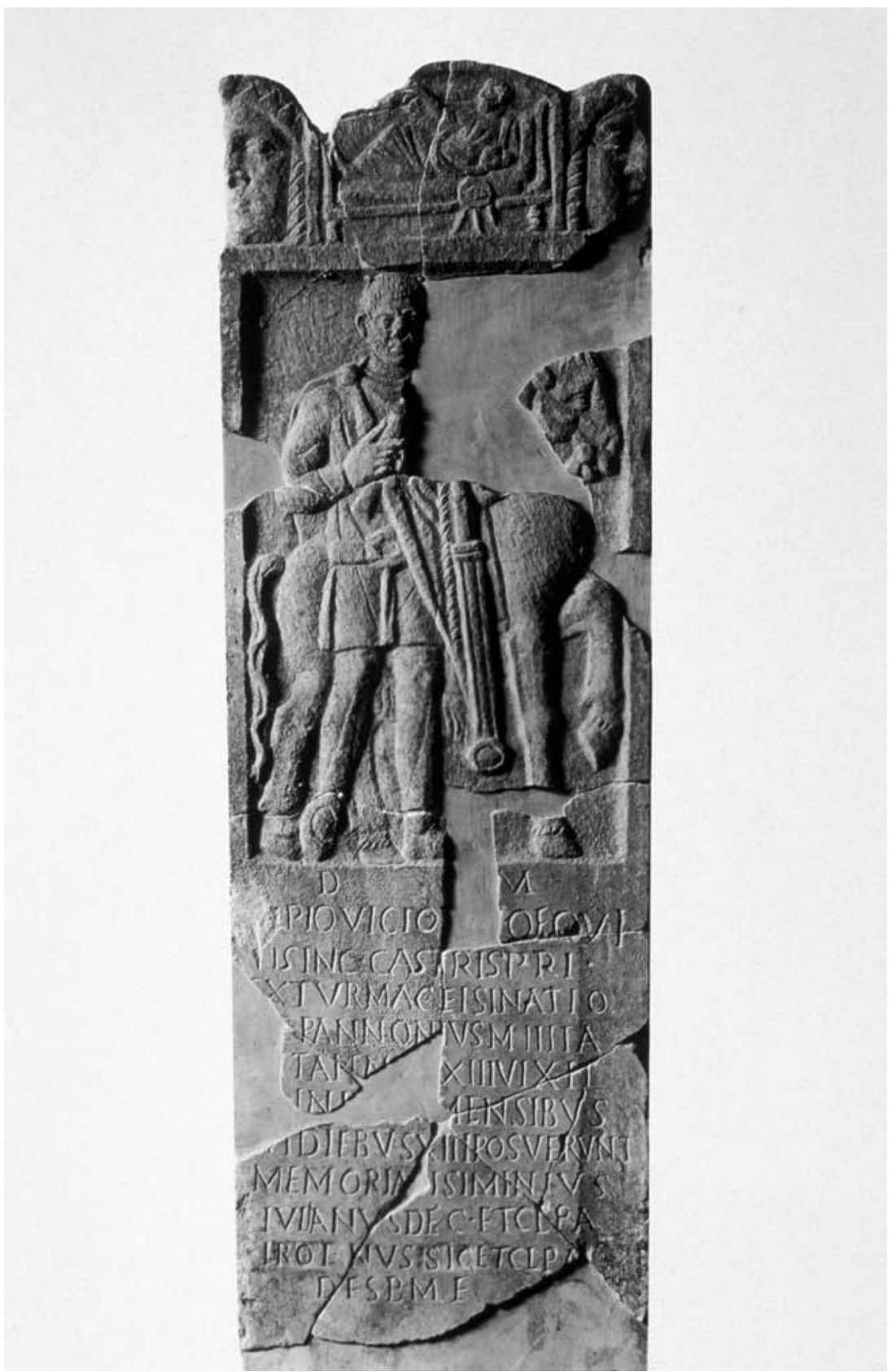

Fig. 3. Third century gravestone of eques singularis Augusti Ulpius Victorinus. Musei Vaticani, Rome, Italy. Photograph: Musei Vaticani. 


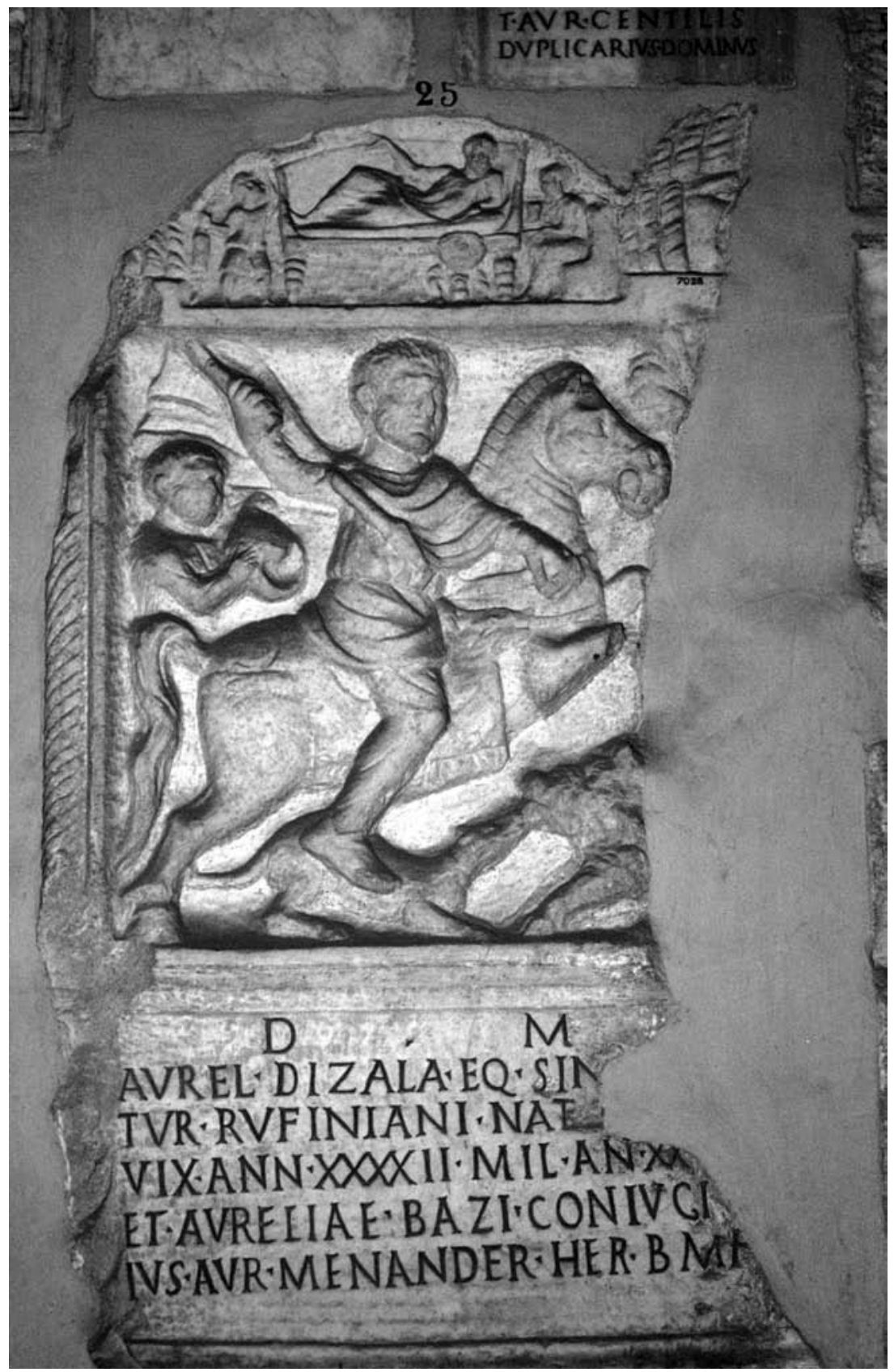

Fig. 4. Third century gravestone of eques singularis Augusti Aurelius Dizala. Musei Vaticani, Rome, Italy. Photograph: J.C.N. Coulston. 


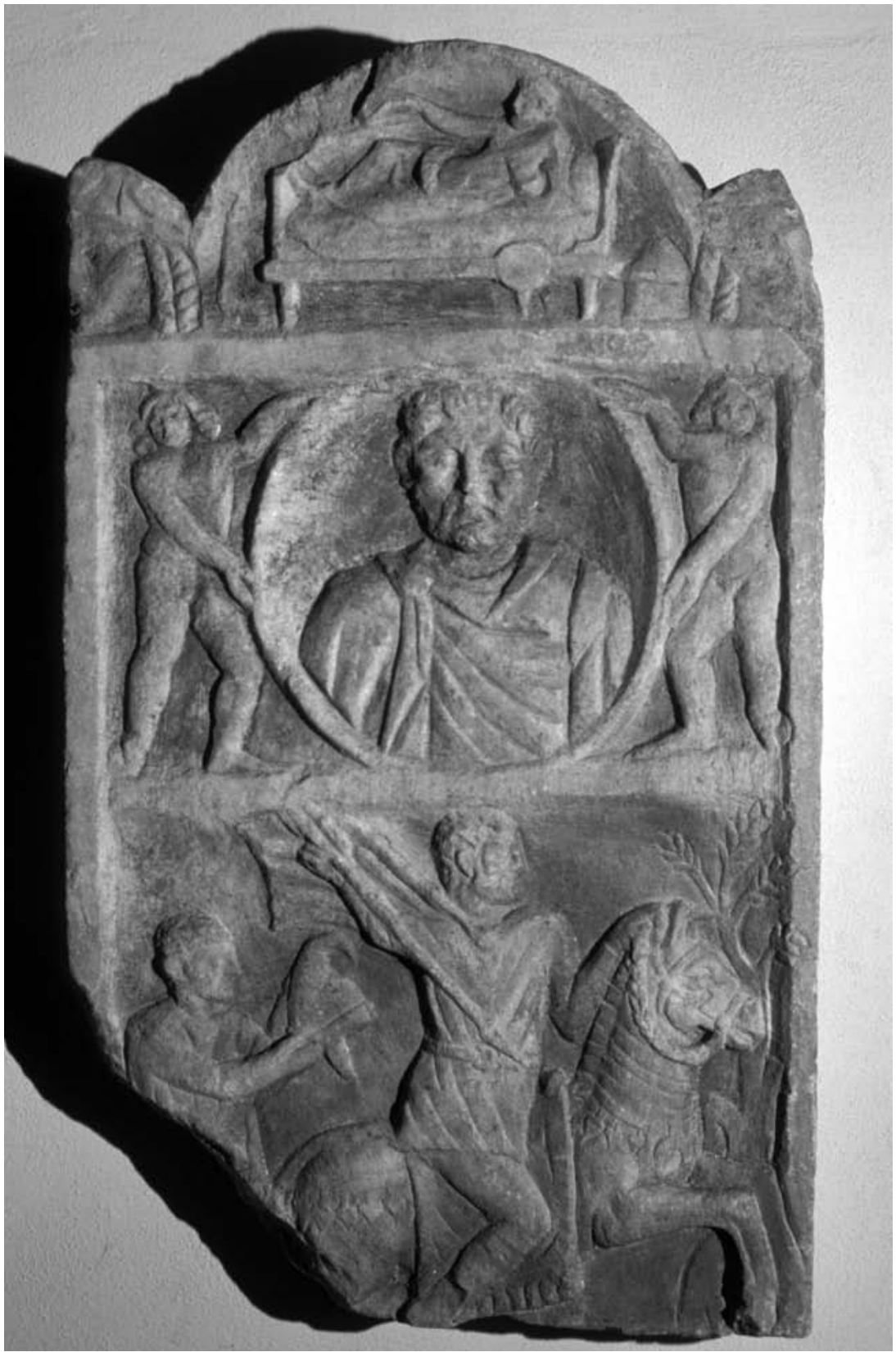

Fig. 5. Third century gravestone of an unknown eques singularis Augusti. Museo Archeologico, Salò, Italy. Photograph: J.C.N. Coulston. 


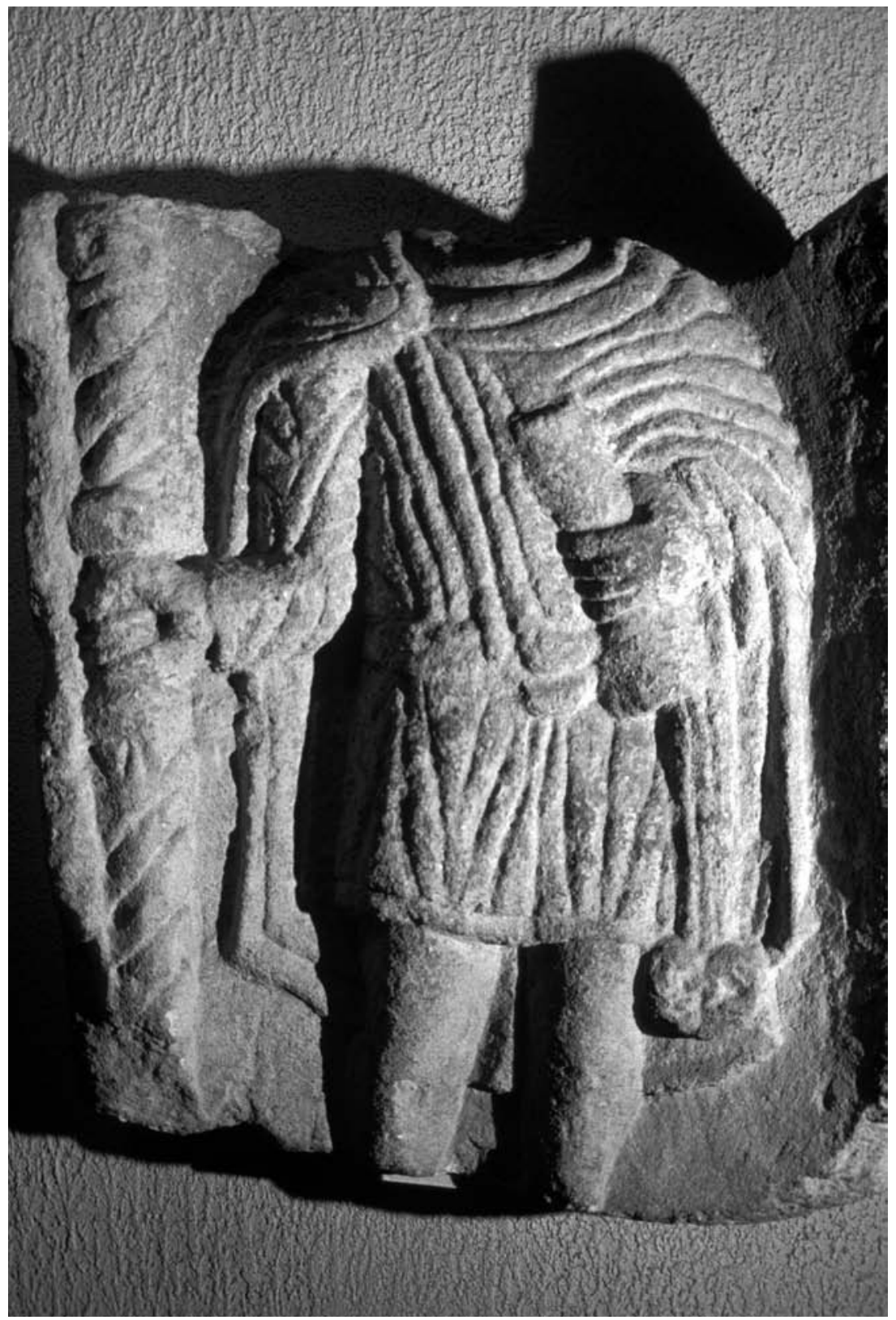

Fig. 6. Third century gravestone of an unknown soldier. Roman Baths Museum, Bath, England. Photograph: J.C.N. Coulston. 


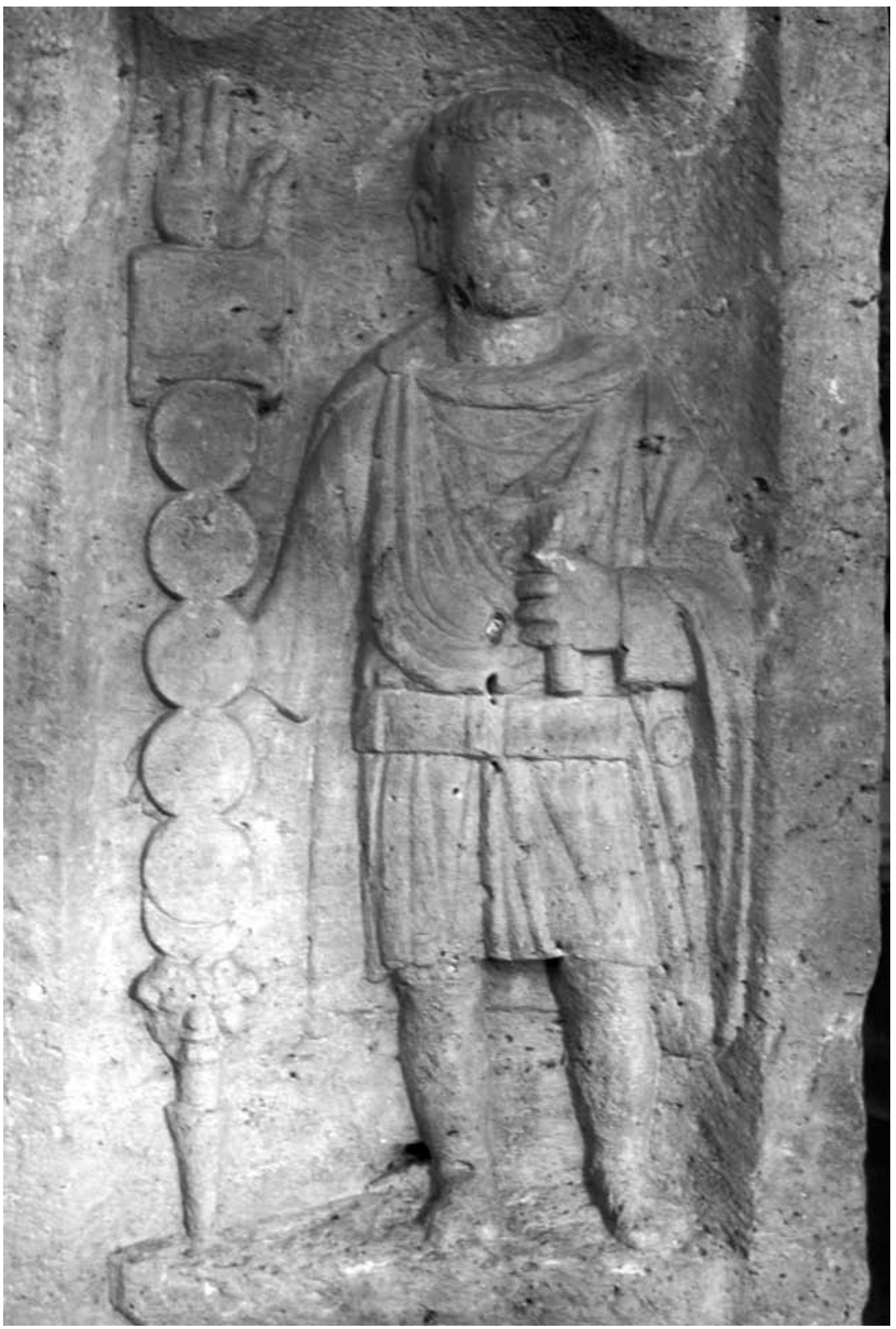

Fig. 7. Third century sarcophagus, detail of signifer figure. Aquincum Museum, Hungary. Photograph: J.C.N. Coulston. 


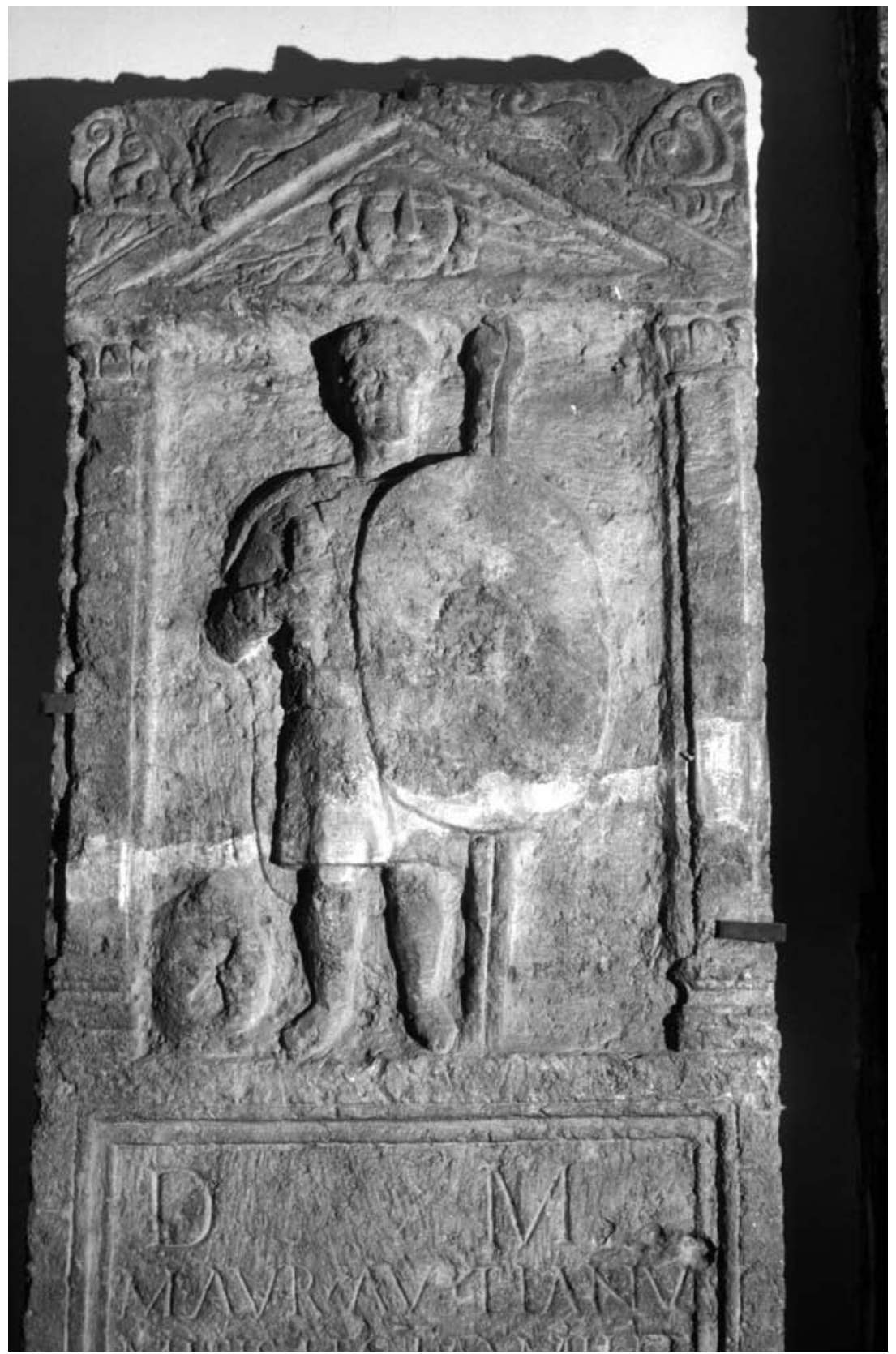

Fig. 8. Third century gravestone of M. Aurelius Avitianus, legio II Adiutrix. Aquincum Museum, Hungary. Photograph: J.C.N. Coulston. 


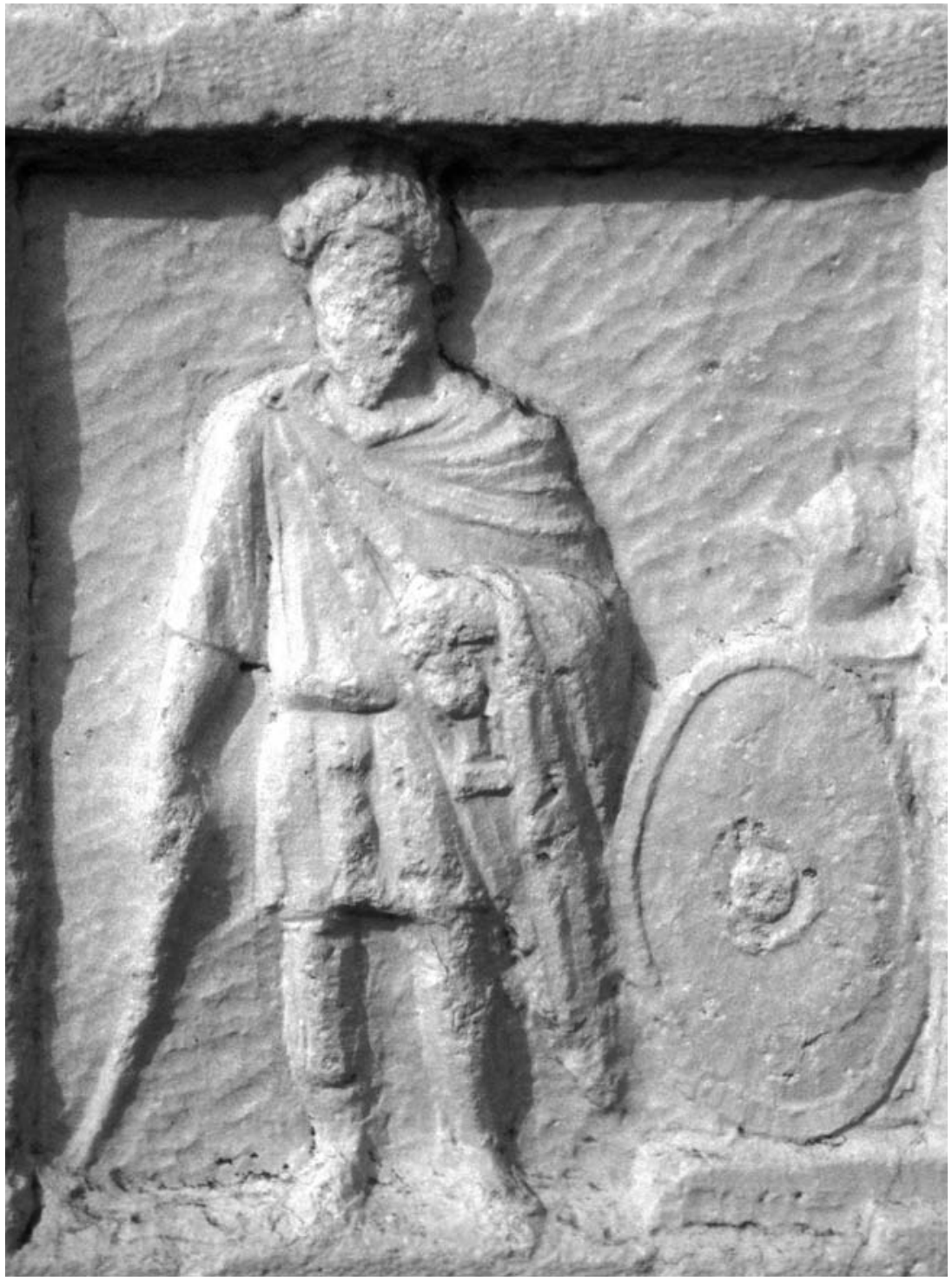

Fig. 9. Third century gravestone of Iulius Aufidius, legio XVI Flavia firma. Veria Museum, Greece. Photograph: J.C.N. Coulston. 


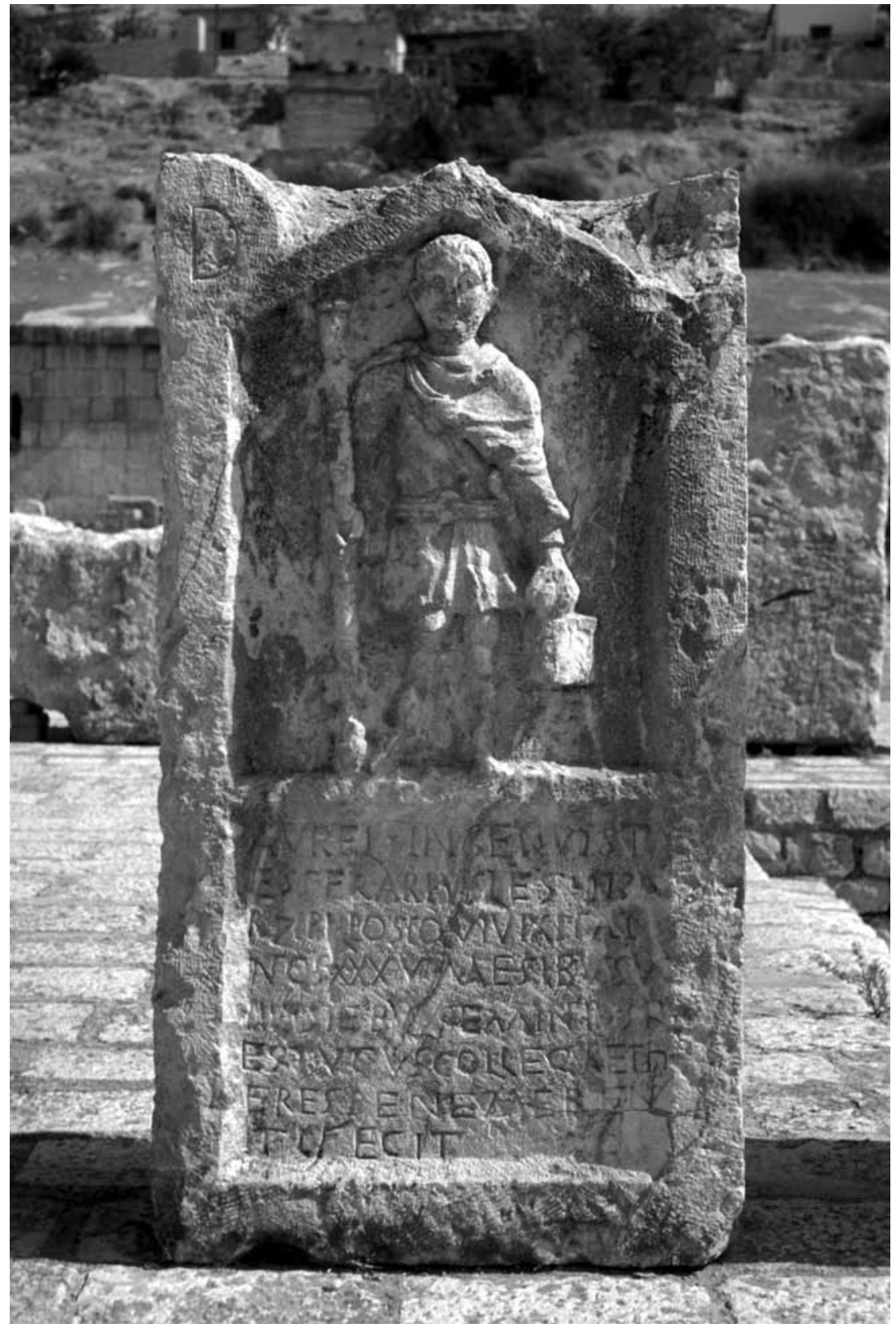

Fig. 10. Third century gravestone of Aurelius Ingenuus, tesserarius in legio II Parthica. Apamea/Qalaat al-Mudiq, caravanserai museum, Syria. Photograph: M.C. Bishop. 


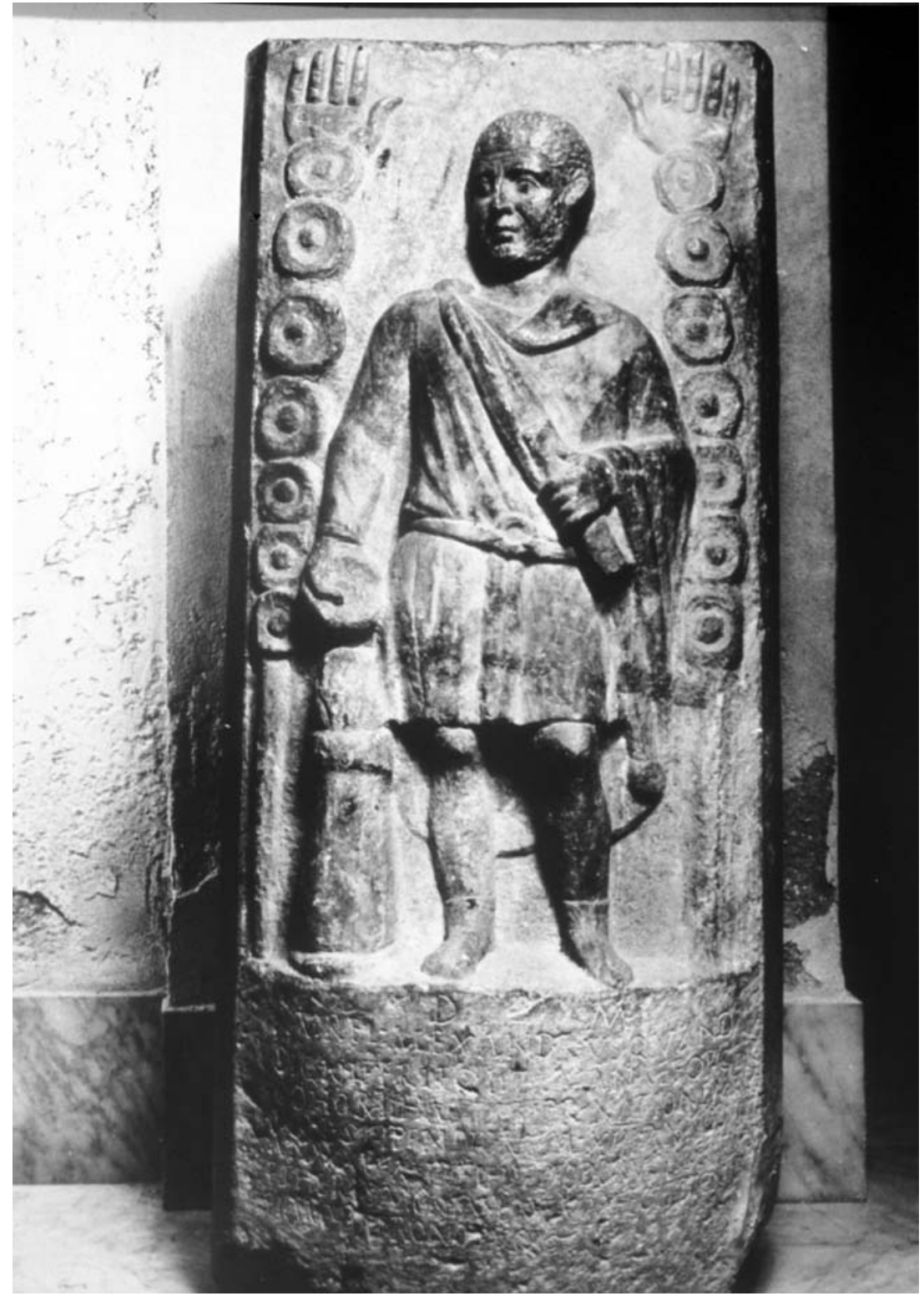

Fig. 11. Third century gravestone of Aurelius Alexander, legio II Traiana fortis. Greco-Roman Museum, Alexandria, Egypt. Photograph: Katholieke Universiteit Leuven. 


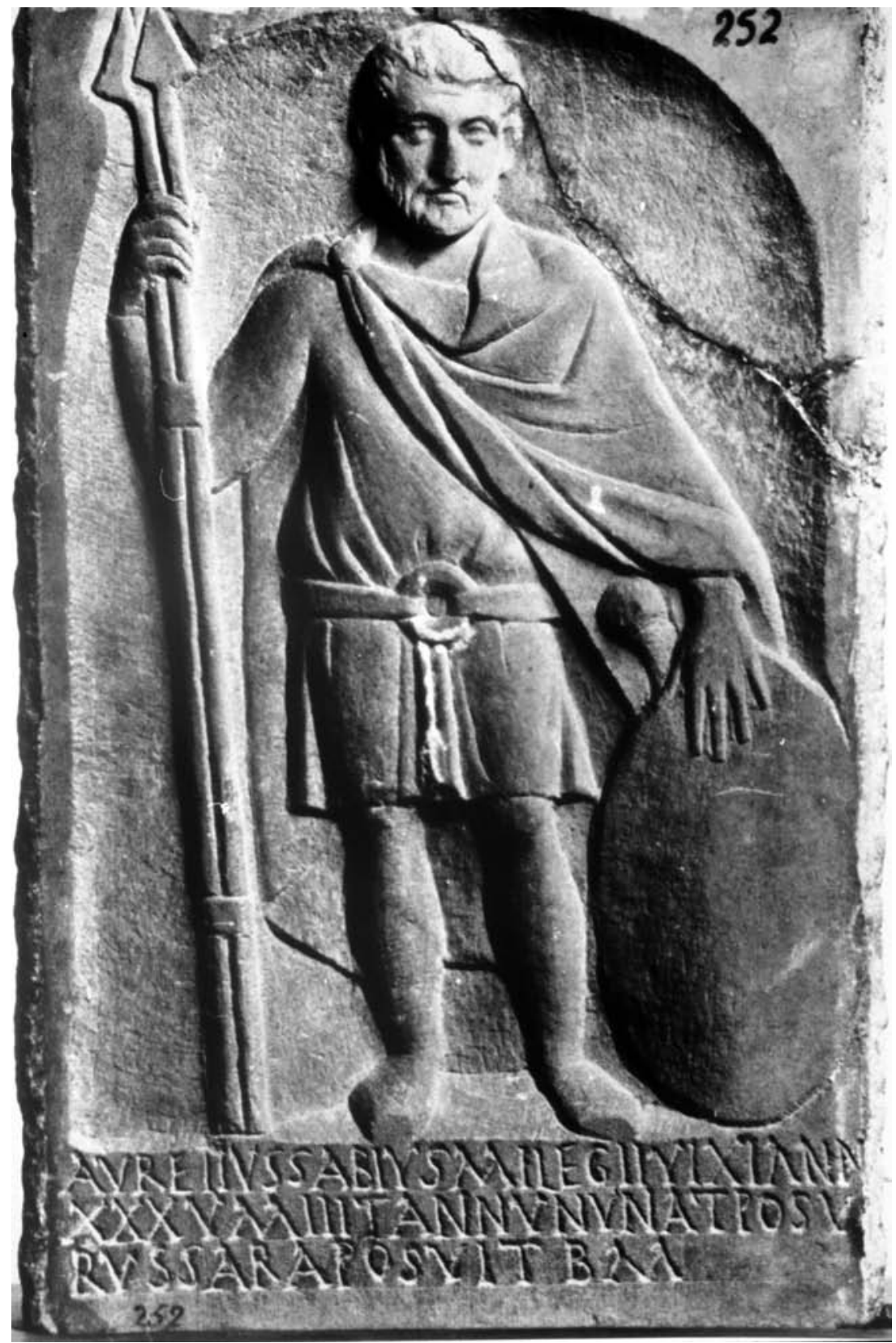

Fig. 12. Third century gravestone of Aurelius Sabius, legio II Traiana fortis. Greco-Roman Museum, Alexandria, Egypt. Photograph: Katholieke Universiteit Leuven. 